\title{
Czeskie lokalne struktury \\ opozycyjne w 1989 r. w perspektywie oral history ${ }^{1}$
}

Wstęp: czechosłowacki listopad 1989

17 listopada jest w najnowszej historii czeskiej datą magiczną. 17 listopada 1939 r. stał się symbolicznym dniem walki narodu czeskiego przeciwko nazizmowi. Po serii demonstracji przeciw niemieckim okupantom jesienią 1939 (28 października i 15 listopada), kiedy to zastrzelony został student wydziału lekarskiego Uniwersytetu Karola Jan Opletal, Adolf Hitler rozkazał zamknąć czeskie szkoły wyższe. Natychmiast stracono dziewięciu czeskich studentów. $1200 \mathrm{z}$ nich trafiło do obozów koncentracyjnych. 17 listopada został później ogłoszony międzynarodowym dniem studentów.

Pięćdziesiąt lat później, 17 listopada 1989 r., w celu uczczenia tamtych wydarzeń, odbyła się uroczystość wspomnieniowa, organizowana m.in. przez

Niniejsze studium prezentuje fragment badań w ramach projektu Průběh Sametové revoluce ve vybraných městech Jihočeského kraje v komparativní perspektivě, [Przebieg Aksamitnej Rewolucji w wybranych miastach kraju [odpowiednik województwa] Południowoczeskiego w perspektywie porównawczej], realizowanego przy wsparciu finansowym Agencji Grantowej Republiki Czeskiej; numer projektu: 13-15049S. 
oficjalną organizację proreżimową - Socjalistyczny Związek Młodzieży. Część z początkowo dwudziestotysięcznego tłumu po skończeniu oficjalnej części uroczystości udała się do centrum miasta, gdzie na Národní Tř́ídzie, niedaleko historycznego budynku Teatru Narodowego, czescy studenci zostali napadnięci przez jednostki porządkowe Bezpieczeństwa Publicznego i ciężko pobici. Wydarzenia 17 listopada stały się zwiastunem upadku systemu komunistycznego w Czechosłowacji. W proteście przeciw atakowi komunistycznych sił policyjnych przeciwko studentom ich koledzy i teatry praskie ogłosiły strajk i tym samym wznieciły falę akcji antyreżimowych, których skutkiem był upadek reżimu i powrót demokracji w kraju. 17 listopada został ogłoszony dniem walki o wolność i demokrację, świętem państwowym Republiki Czechosłowackiej, a potem także Republiki Czeskiej.

Wydarzenia listopada 1989 r. weszły do historii jako tzw. Aksamitna Rewolucja. Określenie to dotyczy jednak samego przejęcia władzy przez nowe elity, co przebiegło bez przemocy, bez przelewu krwi - inaczej niż na przykład w Rumunii. Jak widać, przemocy, która jest jedną z cech charakterystycznych rewolucji, nie brakowało także tutaj, na samym jej początku. Wydarzenia na Národní Třídzie nie miały nic wspólnego z aksamitem.

Przebieg Aksamitnej Rewolucji w jej centrach - Pradze i Bratysławie, podobnie jak działalność i struktury czeskich dysydentów przed listopadem 1989 r., są obecnie tematami dosyć dobrze opracowanymi, poświęca im uwagę historiografia czeska i europejska².

Spośród nich wymieńmy przynajmniej kilka: M. Pullmann, Konec exeprimetnu. Přestavba a pád komunismu v Československu, Praga 2011; J. Suk, Labyrintem revoluce, Praga 2003; idem, Občanskéfórum, t. I, II, Brno 1997-1998; M. Otáhal, Opozice, moc, společnost, Praga 1994; idem, Opoziční proudy v české společnosti 1969-1989, Praga 2011; M. Otáhal, M. Vaněk, Sto studentských revolucí, Praga 1999; Vítězové? Poražení?, wyd. P. Urbášek, M. Vaněk, Praga 2005; Mocní? A bezmocní?, red. M. Vaněk, Praga 2006; Obyčejní lidé...?!, wyd. M. Vaněk, Praga 2009; J. Měchýř, Velký převrat či snad revoluce Sametová?, Praga 1999; J. Bureš, Občanské forum, Praga-Pilzno 2007; Proč jsme v listopadu vyšli do ulic?, red. T. Brod, Brno 1999; itd. Spośród prac zagranicznych wymieńmy choćby te: B. Blehova, Der Fall des Komunismus in der Tschechoslovakei, Wiedeń 2006; E. Zadoružnjuk, Ot krušenija Pražskoj vesny k triumfu „barchantnoj" rezoluci, Moskwa 2008; R. Shepherd, Czechoslovakia: the Velvet Revolution and Beyond, Bansingston 2000; J.H. Krapfl, Revolution with a human face: politics, culture and commmunity in Czechoslovakia 1989-1992, Stanford 2007; Samtene Revolution, red. N. Perzi, B. Blehova, P. Bachmaier, Frankfurt nad Menem 2009 i wiele innych. 
Zdecydowanie mniej znanym i słabiej przebadanym kontekstem Aksamitnej Rewolucji w Czechosłowacji jest jej przebieg w poszczególnych czeskich miastach i regionach. Jeszcze wyraźniej widać braki w badaniach nad lokalnymi strukturami opozycyjnymi. Szczególne zainteresowanie wydarzeniami w największych miastach, przede wszystkim w Pradze, jest zrozumiałe. Właśnie tu, w politycznym centrum kraju, przebiegały kluczowe procesy - od wydarzeń na Národní Třídzie po negocjacje między przedstawicielami władzy komunistycznej i opozycji na czele z nowo powstałym Forum Obywatelskim. Jednak najnowsze wyniki badań historycznych jasno wskazują, że równie istotna dla pełnego powodzenia i błyskawicznego rozprzestrzenienia się Aksamitnej Rewolucji była sytuacja w regionach poza Pragą. Właśnie połączenie działań opozycji w Pradze i poza nią było zasadniczym warunkiem powodzenia zmian demokratycznych.

\section{Motywy i stan badań nad Aksamitną Rewolucją na poziomie lokalnym} Przebieg Aksamitnej Rewolucji poza Pragą przez długi czas był w historiografii czeskiej tematem raczej marginalizowanym, ale już od początku lat 90. XX w. stopniowo pogłębiana jest wiedza o tej problematyce. Uwaga badaczy koncentruje się szczególnie na regionie północnoczeskim oraz zachodnioczeskim, gdzie kolejne etapy Aksamitnej Rewolucji są najlepiej udokumentowane.

W tym kontekście warto wspomnieć szczególnie prace Miroslava Vaňka ${ }^{3}$, Catherin Perrón ${ }^{4}$ czy Miroslava Antona ${ }^{5}$. Do tych pojedynczych prac odwoływał się szereg projektów badawczych, które przyniosły znaczny, aczkolwiek nadal jeszcze nie wystarczający, postęp w poznaniu tej problematyki. Lukas Valeš opublikował serię monografii na temat przebiegu

3 M. Vaněk, Listopadové události roku 1989 v Plzni, [w:] Dvě desetiletí pred listopadem, red. E. Mandler, Praga 1993; idem, Předehra k17. Listopadu: Ekologické demonstrace v Teplicích, [w:] Historické studie: K sedmdesátinám M. Otáhala, Praga 1998. Obszerniej o wpływie ekologii na formowanie opozycji czechosłowackiej i nastrojów antyreżimowych w społeczeństwie czechosłowackim patrz: M. Vaněk, Nedalo se tady dýchat. Ekologie v českých zemích v letech 1968 až 1989, Praga 1996.

4 C. Perrón, Vznik nové lokální politické elity v Plzni, „Politologická revue”, 1998/1, s. $61-81$.

$5 \quad$ M. Anton, Listopad 1989 v Plzni, Pilzno 1999. 
Aksamitnej Rewolucji w najważniejszych miastach zachodnich Czech ${ }^{6}$. Temat Aksamitnej Rewolucji w Pilznie opracował badacz tego regionu Martin Boštík ${ }^{7}$, Jiří Petráš poświęcił się zagadnieniu wydarzeń listopadowych $\mathrm{z}$ perspektywy lokalnych elit reżimu komunistycznego $\mathrm{w}$ południowych Czechach $^{8}$. W ostatnich latach wyszła także praca porównująca wydarzenia rewolucyjne w 1989 r. na pograniczu czechosłowackim i wschodnioniemieckim?. Dwudziesta rocznica Aksamitnej Rewolucji przyniosła także wiele wspomnień świadków ówczesnych wydarzeń - studentów, uczestników rewolucji itp. Przynajmniej częściowo zmapowały one tę tematykę w miastach Usti nad Labem (północne Czechy), Zlinie (dawniej Gottwaldov - wschodnie Morawy), Opavie (czeska część Śląska) itp. ${ }^{10}$

Tym sprofilowanym regionalnie studiom wyszły naprzeciw także dwa wielkie ogólnopaństwowe projekty, realizowane przez Centrum Oral History Instytutu Historii Współczesnej Akademii Nauk Republiki Czeskiej, które w formie książkowej ukazały się pod tytułami Vitězové? Poražení? ${ }^{11}$

6 Rok 1989 v Plzni a západních Čechách, Plzeň 2003; L. Valeš, Listopad 89 v Klatovech, red. L. Valeš, Klatovy 2005; L. Valeš, Zrod demokratických politických systémů okresů Klatovy, Domažlice a Tachov, Pilzno 2007.

7 M. Boštík, Sametová revoluce v Litomyšli, Litomyšl 2009.

8 J. Petráš, Listopad 1989 ve světle pramenů jihočeského krajského výboru KSČ České Budějovice, „Výběr, časopis pro historii a vlastivědu jižních Čech“, XXXIV, 1997, nr 4.

9 B. Čermáková et al., Občanská odvaha vstupuje do polityki: 1989/199o: Občanské forum v Chebu, Nové forum v Plavně, Praga 2009. Badania historyczne wydarzeń listopadowych na terenie Niemiec należą do najbardziej zaawansowanych w całej Europie Środkowej i Wschodniej. Z bogatej literatury przypomnijmy przynajmniej: S. Rassloff, Friedliche Revolution und Landesgründung in Thüringen 1989/9o, Erfurt 2009; A. Dornheim, Politischer Umbruch in Erfurt 1989/199o, Wien 1995; B. Linder, Für ein offenes Land mit freiem Menschen, Lipsk 1994

10 Sametová revoluce v Ústí nad Labem. Svědectví studentů po dvaceti letech, red. J. Rokoský, Ústí nad Labem 2009; F. Bobák, Moje svědectví o listopadových událostech ve Zlíně, Zlín 2009; A. Binar, R. Plaček, Opava 1989 ve vzpominkách, Opava 2009.

11 Vítězové? Poražení? I, II, wyd. M. Vaněk, M. Urbášek (red.), Praha 2005. Chodziło o publikację transkrypcji około 50 wywiadów z przedstawicielami czeskiego środowiska dysydenckiego i reżimu komunistycznego. Pełna liczba wywiadów zrealizowanych w ramach tego projektu wynosiła ok. 20o. Ich transkrypcje i nagrania audio (niekiedy wideo) są przechowywane w archiwum Centrum Oral History Instytutu Historii Współczesnej Akademii Nauk Republiki Czeskiej [AN RCz]. Ich analiza wyszła w oddzielnej pracy Mocní? A bezmocní?, red. M. Vaněk, Praga 2005. 


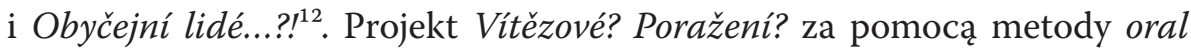
history zaprezentował przegląd narracji biograficznych ponad 120 przedstawicieli czeskiego środowiska dysydenckiego i aparatu komunistycznego. Już od początku celem tego projektu było pozyskanie nie tylko wywiadów biograficznych z osobistościami z centrum, ale także i przedstawicielami opozycji i aparatu władzy w regionach. Podobne podejście cechuje też drugi projekt o nazwie Obyčejní lidé...?? , który utrwalił narracje biograficzne czeskich robotników i inteligencji w okresie po 1968 r. - w epoce tzw. normalizacji ${ }^{13}$. Ponieważ oba projekty zawierają ponad 200 wywiadów, badacze zajmujący się badaniem problematyki regionalnej zyskali interesujące i relatywnie bogate źródło informacji o tym, jak funkcjonowały mechanizmy władzy poza Pragą, jak się tam formowały struktury opozycyjne, kto je zakładał i jak ludzie ci z perspektywy czasu wspominają swoje ówczesne zaangażowanie w okresie Aksamitnej Rewolucji i później.

Te projekty grantowe były jednocześnie swego rodzaju kulminacją starań części historyków czeskich o uznanie oral history jako relewantnej nowoczesnej metody badań historycznych. Ich wielki sukces sprawił, że próba ta się powiodła, mimo że szczególnie starsze pokolenie historyków odnosiło się do metody oral history raczej nieufnie. Potwierdzeniem tego sukcesu był wybór profesora Miroslava Vanka, najbardziej znaczącego historyka czeskiego zaangażowanego $\mathrm{w}$ ten proces, na przewodniczącego International Oral History Association w $2010 \mathrm{r}$.

Studium niniejsze za punkt wyjścia miało wyżej wspomniane projekty ogólnopaństwowe, ale u jego podstaw leżą badania własne autora, zrealizowane w latach 2001-2007 w zachodnich Czechach. W ramach projektu badano proces destrukcji ustroju komunistycznego i budowę nowych struktur demokratycznych w kilku miastach Kraju Zachodnioczeskiego, takich jak Pilzno, Klatovy, Domazdice, Tachov, Stribro, Cheb itd. Tutaj także metoda oral history - obok tradycyjnych narzędzi badań historycznych - odegrała kluczową rolę. Przy czym - podobnie jak w przypadku projektu Vitězové? Poražení? wywiady przeprowadzono zarówno z tymi, którzy w listopadzie 1989 r. prowadzili i organizowali działania antyreżimowe, jak

12 Obyčejní lidé...?! Pohled do života tzv. mlčící většiny I-III, red. M. Vaněk, Praga 2009.

13 O rozwoju czeskich badań oral history i przygotowaniu obu projektów zob.: Deset let na cestě, red. M. Vaněk, P. Houda, P. Mucke, Praga 2011. 
172 i z przedstawicielami lokalnych i okręgowych struktur reżimu komunistycznego (przedstawiciele miast, komitetów okręgowych partii komunistycznej, dyrektorzy szkół itd.). Do tego projektu nawiązywać będą podobne badania regionalne, dotyczące obszaru południowych $\mathrm{Czech}^{14}$.

Zainteresowanie wydarzeniami $1989 \mathrm{r}$. w poszczególnych miastach i regionach czeskich uzasadnia kilka okoliczności:

1. Struktura osadnicza Republiki Czeskiej. Republika Czeska miała i ma specyficzną strukturę osadniczą, na którą składa się dziś około 6350 gmin. Około 70\% mieszkańców żyje poza wielkimi centrami miejskimi - na wsi lub w małych i średnich miastach. Jeżeli więc chcemy zrekonstruować rozwój historyczny społeczeństwa czeskiego, musimy zacząć badania właśnie na tym poziomie.

2. Rewolucja 1989 r. nie zaczęła się w Pradze. Jednym z wielu paradoksów Aksamitnej Rewolucji w Czechosłowacji jest fakt, że pierwsze listopadowe demonstracje antyreżimowe miały miejsce poza stolicą, a mianowicie w północnych Czechach - przede wszystkim w mieście Teplice. Jest to tym bardziej interesujące, że właśnie regiony północnych Czech i północnych Moraw cieszyły się szczególnymi względami aparatu komunistycznego. Powodem była wysoka koncentracja przemysłu ciężkiego: wydobywczego, hutniczego i chemicznego, związana m.in. $\mathrm{z}$ wydobyciem węgla brunatnego (północne Czechy) i czarnego (północne Morawy). Wydobycie węgla i koncentracja przemysłu oznaczały z jednej strony wysoką liczbę robotników a więc grupy szczególnie uprzywilejowanej przez reżim, ale przede wszystkim stale pogarszający się stan środowiska naturalnego i związane z tym problemy zdrowotne tutejszych mieszkańców. Paradoksem tamtej epoki, a zarazem cechą charakterystyczną $\mathrm{w}$ kontekście powstania lokalnych struktur opozycyjnych był fakt, że impulsem do działań antyreżimowych nie była z początku polityka, próba zmiany czy obalenia ustroju komunistycznego. Przeciwnie, sprzeciw wobec niego wynikał z konkretów - chodziło w tym przypadku o ochronę przyrody czy też próbę powstrzymania dalszej dewastacji środowiska, co bezpośrednio zagrażało życiu i zdrowiu ludzi w północnych Czechach. Od połowy października 1989 r. w Teplicach trwały nieustanne inwersje. Koncentracja tlenku siarki i ilość opadłego

14 Zob. projekt: Průběh Sametové revoluce ve vybraných městech Jihočeského kraje vomparativní perspektivě. 
popiołu lotnego z elektrowni północnoczeskich kilkakrotnie przekroczyły ustawowe limity. Urzędy wzywały mieszkańców, by nie wietrzyli mieszkań i w miarę możliwości nie wychodzili. Inwersje trwały nieprzerwanie do połowy listopada. Już 8 listopada $1989 \mathrm{r}$. w Teplicach pojawiły się antyreżimowe ulotki, wzywające mieszkańców na manifestację 11 listopada. Pierwsza demonstracja listopadowa w Czechosłowacji w 1989 r. miała więc miejsce właśnie 11 listopada; udział w niej wzięło prawie 800 osób. Jak już wspomniano, zwołano ją z konkretnych powodów, a jej organizatorzy z początku nie chcieli nawet, aby przerodziła się w protest jednoznacznie polityczny. Jeden z aktywnych uczestników demonstracji, Jan Sajdl, zauważa: „Nikt z nas nie lubił komunistów, ale trzymaliśmy się tego, że protest nie będzie polityczny. Naprawdę chodziło nam tylko o powietrze. Ale na placu pojawił się jakiś człowiek, który zaczął mówić o sprawach politycznych. Powiedzieliśmy mu, że z tym to nie tutaj. Niech sobie stąd idzie"15. Świadczyły o tym także hasła manifestacji: „Dajcie nam oddychać” czy „Chcemy czystego powietrza”. Demonstracje trwały i intensyfikowały się w kolejnych dniach - 12 i 13 listopada, wzięły w nich udział tysiące osób, doszło także do starć z wezwanymi na miejsce jednostkami policji. Kierownictwo komitetu okręgowego ${ }^{16}$ Komunistycznej Partii Czechosłowacji $[\mathrm{KPCz}]$ w Teplicach ostatecznie było zmuszone do zgody na publiczną dyskusję o stanie środowiska naturalnego na miejscowym stadionie. Jej organizację przerwały jednak wydarzenia 17 listopada, które doprowadziły do definitywnego upadku reżimu. Ponieważ bezpośrednim impulsem do demonstracji na północy Czech była gęsta mgła spowodowana nieprzerwaną inwersją i smog - efekt działania tutejszych elektrowni, demonstracje w Teplicach nazywa się niekiedy „smogową rewolucją"

3. Rozprzestrzenienie się Aksamitnej Rewolucji z Pragi do regionów i poszczególnych czeskich miast było kluczowym warunkiem jej sukcesu. Dotychczasowe działania czeskiej opozycji i środowisk dysydenckich ${ }^{18}$

15 A. Viktora, Demonstrace v listopadu 1989 rozpoutal učeň v Teplicích, [w:] http:// zpravy.idnes.cz/demonstrace-v-listopadu-1989-rozpoutal-ucen-v-teplicich-pp6-/domaci.aspx?c=Ao91102_141116_domaci_itu (dostęp: 10 I 2013 r.).

16 Okręg odpowiednik powiatu.

17 Więcej zob.: M. Vaněk, Nedalo se tady dýchat...; idem, Předehra k 17. listopadu...

18 Więcej zob.: M. Otáhal, Opoziční proudy v české společnosti 1969-1989, Praga 2011, Opozice a odpor proti komunistickému režimu v Československu, red. P. Blažek, Praga 2005. 
174 kończyły się niepowodzeniem między innymi właśnie dlatego, że niemal w całości koncentrowały się w wielkich centrach - Pradze, Brnie, Bratysławie. Jeżeli Aksamitna Rewolucja miała odnieść realny sukces, tym razem w bieg wydarzeń musiał zostać włączony dosłownie cały kraj. Wydarzenia rewolucyjne nie ograniczały się do centrali - czeskie społeczeństwo przeżywało Listopad $1989 \mathrm{r}$. bezpośrednio w miejscach, w których żyło. Dobrze zdawali sobie $\mathrm{z}$ tego sprawę przedstawiciele komunistycznego aparatu władzy. Na podstawie dotychczasowych doświadczeń liczyli oni, że pierwsza fala demonstracji i niepokojów obywatelskich ograniczy się do Pragi i nie znajdzie szerszego poparcia $\mathrm{w}$ regionach - podobnie jak w przypadku poprzednich antyreżimowych wystąpień opozycji. Przeciwnie, dotychczas relatywnie spokojne kraje ${ }^{19}$ miały być - z perspektywy wielkiej części członków Komitetu Centralnego Komunistycznej Partii Czechosłowacji (KC KPCz) - zaporą przeciwko „praskiemu radykalizmowi”. Świadczą o tym m.in. słowa sekretarza KC KPCz Jana Fojtíka z poniedziałku 20 listopada 1989 r.: „Ta próba przewrotu państwowego nie zakończy się sukcesem, ponieważ jego inicjatorom nie uda się wywołać strajku generalnego, o który im chodzi. Pokażemy im taką demonstrację siły, że stracą chęć. Do Pragi zjadą tysiące ludzi z okręgów i krajów i ochłodzą te rozpalone głowy. Pokażą im, że Praga to nie cała republika" ${ }^{20}$. Gdyby rzeczywiście udało się uniemożliwić aktywizację społeczeństwa w innych regionach republiki, Praga zostałaby odcięta, co z kolei wpłynęłoby negatywnie na rozwój wydarzeń w samym centrum władzy i mogłoby znacznie zmienić układ sił między władzą a rodzącą się opozycją i zdecydowanie zahamować cały proces demokratyzacyjny. Upadek systemu komunistycznego i wprowadzanie demokracji przebiegłoby zupełnie inaczej i w warunkach znacznie trudniejszych z punktu widzenia opozycji.

4. Czeska polityka lokalna w momentach znaczących zwrotów historycznych wytwarza bardzo specyficzny system polityczny, który w dużym stopniu abstrahuje od potocznego rozumienia tej polityki jako niższego poziomu państwowego życia politycznego. Przeciwnie, w takich chwilach charakteryzuje się własną dynamiką i formą. Polityka na poziomie gmin a przede wszystkim miast nie kopiuje bowiem mechanicznie wydarzeń ogólnopaństwowych, ale reaguje na nie w sposób bardzo kreatywny, dostosowany do specyficznych warunków lokalnych. Na charakter tej reakcji

19 Kraj odpowiednik województwa.

20 M. Otáhal, Opozice, moc, společnost, Praga 1994, s. 101. 
wpływ ma całe spektrum faktorów - wielkość miejscowości, jej polityczne tradycje, jej polityczna kultura jako taka, struktura społeczna, demograficzna, edukacyjna i ekonomiczna, ciągłość (lub jej zaburzenia) osadnictwa, patriotyzm lokalny, poziom związku mieszkańców z miejscem zamieszkania, jakość elit politycznych itd. Podobnie było w 1989 r. Właśnie wtedy czeska polityka lokalna zyskała wyjątkowy poziom autonomii. Każde miasto czeskie weszło - mimo pewnych cech wspólnych - na swoją własną drogę przejścia od posttotalitarnego systemu autorytarnego ${ }^{21}$ do systemu demokratycznego, a więc między innymi także na drogę ku demokratycznej polityce samorządowej. Ten autonomiczny rozwój był możliwy m.in. dzięki temu, że zarówno elity aparatu władzy, jak i przedstawiciele formującej się opozycji w centrali zajmowali się głównie zagadnieniami polityki ogólnokrajowej. Rozwój sytuacji poza Pragą, chociaż istotny zarówno dla władzy, jak i dla opozycji, był w wielkim stopniu pozostawiony sam sobie.

\section{Typologia lokalnych struktur opozycyjnych}

Kim więc byli ludzie w czeskich regionach, którzy bezpośrednio po wydarzeniach na Národní Třídzie chcieli otwarcie zaangażować się przeciwko dotychczasowemu systemowi komunistycznemu, który w tamtym czasie pewnie trzymał wszystkie narzędzia władzy - tajną policję, siły porządkowe, armię? Co więcej, w czasie, kiedy nie było wcale pewne, jak się zakończy konfrontacja z władzą. System komunistyczny upadł co prawda w sąsiednim NRD, stopniowo ustępował w Polsce i na Węgrzech, ale nic nie wskazywało na to, że czechosłowaccy komuniści chcą zrzec się władzy. Warto podkreślić, że owi regionalni działacze chcieli zaangażować się w miastach i miasteczkach, gdzie nie można było zachować anonimowości, jak w przypadku wielkich miast?

Zanim odpowiemy sobie na to pytanie, zatrzymajmy się u samego pojęcia dysydent, potocznie używanego w celu określenia przedstawicieli opozycji antyreżimowej.

Próbując zdefiniować dysydenta, możemy rozpocząć od etymologii tego słowa. Jego podstawą jest łaciński czasownik dissidere - odchylać się, różnić, być innego zdania, nie zgadzać się. W swoim dzisiejszym znaczeniu

21 Autor wykorzystuje tu klasyfikację politologa Juana Linza. Więcej zob.: V. Dvořáková, J. Kunc, O přechodech k demokracii, Praga 1994; B. Říchová, Přehled moderních politologických teorií, Praga 2006. 
termin był po raz pierwszy użyty dla określenia angielskich protestantów, którzy nie należeli do Kościoła anglikańskiego ${ }^{22}$. W krajach bloku wschodniego określenie to pojawia się po raz pierwszy w kontekście Związku Radzieckiego jako oznaczenie kilkudziesięciu obywateli, oficjalnie wyrażających swój sprzeciw wobec łamania praw człowieka i brutalnym praktykom władz. Stamtąd w tym samym znaczeniu przeniósł się do innych krajów ówczesnego bloku wschodniego. Socjolożka i aktywna dysydentka Jiřina Šiklová tak definiuje postawę dysydencką: „W latach 70. XX w. słowo to oznaczało niezależną postawę obywatelską w totalitarnych krajach komunistycznych, gdzie nielegalna opozycja polityczna nie mogła istnieć. Cechą charakterystyczną postawy dysydenckiej była systematyczna i publiczna obrona praw człowieka i praw obywatelskich, krytyka systemu totalitarnego i skutków jego działania w społeczeństwie, aktywna postawa obywatelska, którą cechowała współodpowiedzialność za powszechnie obowiązujące stosunki, obrona zasad wolności i solidarność z każdym, kogo prawa obywatelskie i prawa człowieka są ograniczone. Z takiej postawy jednostek, grup powstawały inicjatywy obywatelskie: polski KOR, czeska Karta 77, VONS i inne"23.

Gdyby posługiwać się taką definicją postawy dysydenckiej, to co najmniej do wiosny 1989 r. żadne środowisko dysydenckie na poziomie lokalnym nie istniało. W przeważającej większości czeskich miast i gmin (z wyjątkiem Pragi i Brna czy Ołomuńca) nie spotkamy się z wyżej opisanymi, politycznymi, lub częściowo politycznymi działaniami. Nawet ludzie, którzy w regionach pisali czy przepisywali samizdaty, kolportowali „nielegalne” druki, i którzy świadomie poświęcali się działalności antyreżimowej czy przez reżim zakazanej, bronią się przed określeniem dysydenci. Jak mówi aktywista z Pilzna, Petr Náhlík: „...my wtedy, o ile pamiętam, za bardzo nie mówiliśmy »dysydenci«, tego używamy dziś raczej dlatego, że jest to powszechnie używany termin” ${ }^{24}$. Jego kolega z miasta Př́́bram Miloš Fryš: „...nie uważam się za niego, za jakiegoś tam dysydenta regionalnego czy innego, to jest po prostu część myślenia etycznego, które po prostu poszukuje albo jakoś rozeznaje się w tym, co jest złe, a co dobre" ${ }^{25}$. Mimo to możemy przy tym terminie

22 Velký sociologický slovník, t. 1, Praga 1996, s. 212.

23 Ibidem.

24 ÚSD, COH, zbiór Rozhovory. Rozmowę z inż. Petrem Náhlíkem przeprowadził Lukáš Valeš, Pilzno, 11 XII 2003 r.

25 ÚSD, COH, zbiór Rozhovory. Rozmowę z M. Fryšem prowadziła Jana Melicharová, Př́ibram, 11 IV 2003 r. 
pozostać. Prawo do tego daje tzw. rozszerzona definicja postawy dysydenckiej, ponownie autorstwa Jiřiny Šiklovej: „....najszerszy sens tego pojęcia uwzględniał ludzi odcinających się od dominującego sposobu myślenia czy stylu życia, nie zgadzających się z oficjalnymi poglądami czy stanowiskami”"26. Kryteria tej definicji nasi „lokalni” dysydenci spełniają. Już porównując „wąski” i „rozszerzony" sens tego pojęcia w interpretacji Jiřiny Šiklovej, widzimy także różnicę priorytetów w działalności dysydentów na poziomie lokalnym i centralnym, a także różnice $w$ ich motywacji. Podczas gdy dysydenci na poziomie centralnym zmierzali do celowej konfrontacji z władzą na przykład przez obronę praw człowieka, inicjowanie akcji zbierania podpisów pod dokumentami antyreżimowymi itd., postawa dysydencka na poziomie lokalnym przejawiała się w niepolitycznej aktywności społeczeństwa obywatelskiego. Dysydenci lokalni nie byli ludźmi polityki. Byli to „tylko" ludzie, którzy chcieli swobodnie realizować swoje wyobrażenia o życiu i stylu życia. A ponieważ reżim nie sprzyjał takiej swobodnej realizacji, wchodzili z nim, często bez takiej intencji, w konflikt. To ich zbliżało do obozu „opozycyjnego”.

Obecny stan badań umożliwia nam podział aktywistów antyreżimowych w listopadzie 1989 r. na następujące grupy:

Pierwszą grupą są sygnatariusze Karty 77 [czes. chartriste - przyp. tłum.] i innych stworzonych przez opozycję dokumentów, które wzywały do przestrzegania praw człowieka lub zwracały uwagę na ich naruszanie. Dodatkowo ludzie, którzy aktywnie uczestniczyli w jakichś antyreżimowych protestach lub brali udział w działalności jakichś organizacji opozycyjnych - obok Karty 77, a także Komitetu obrony niesprawiedliwie prześladowanych, Pokojowego Klubu Johna Lennona itp. ${ }^{27}$ Chociaż wydawałoby się, że grupa ta ze względu na swoją „działalność dysydencką” powinna grać w dniach listopadowych rozstrzygającą rolę, stało się inaczej. Wielu sygnatariuszy dokumentów niektórych grup opozycyjnych ograniczyło swoją działalność opozycyjną właśnie tylko do tego podpisu. Podczas gdy chartriste w Pradze i częściowo w Brnie podpisywali np. Kartę 77 z pełną

26 Velký sociologický slovník...

27 Obok wspomnianej już literatury o czeskiej opozycji i jej strukturze zob. np.: J. Rataj; P. Houda, Československo v proměnách komunistického režimu, Praga 2010; M. Vaněk, Ostrůvky svobody, Praga 2002; M. Otáhal, Podíl tvưrčí inteligence na pádu komunismu, Brno 1999; J. Bureš, J. Charvát, P. Just, M. Štefek, Česká demokracie po roce 1989, Praga 2012. W publikacjach tych znajduje się także kompletna bibliografia czeskiej opozycji i dysydentów. 
świadomością, że jest to pierwszy krok do dalszej działalności opozycyjnej, a ich podpis był jednocześnie celowym aktem politycznym, ludzie spoza tych miast czy spoza głównego kręgu dysydenckiego, reprezentowanego na przykład przez Václava Havla, Václava Bendę czy Rudolfa Batteka, w tym przez „dysydentów” w stolicach krajów, w przeważającej większości rozumieli swój podpis inaczej. Dla wielu z nich podpisanie Karty nie było przede wszystkim wyrazem poglądów politycznych, ale - być może głównie - deklaracją prowolnościowej postawy życiowej. Było protestem przeciw brakowi wolności jako takiej, przeciw konformizmowi nowoczesnego społeczeństwa. Formy tego protestu bywały bardzo różne - od udziału w koncertach zespołów undergroundowych, podpisywania dokumentów antyreżimowych aż po zażywanie narkotyków. Nie chodziło więc głównie o politykę, ale o wyraz wolności i protestu przeciw jakimkolwiek autorytetom. Tę grupę trafnie opisuje sygnatariusz Karty 77 z Pilzna Jan Thoma: „Więc jeżeli chodzi o Kartę, to tutaj w Pilznie, w Kraju Zachodnioczeskim, było 35 sygnatariuszy Karty. Znaczna część z nich to podpisała i na tym się skończyło... A poza tym byli ludzie tacy jak ja, powiedziałbym trochę dewianci" ${ }^{28}$. Istotnym faktem jest bardzo niska liczba sygnatariuszy z tego regionu. Ówczesny Kraj Zachodnioczeski, który odpowiadał terytorium dzisiejszych krajów Pilzneńskiego i Karlowarskiego, był rozległym terenem, gdzie żyło ponad milion mieszkańców. Tylko 35 z nich podpisało Kartę 77, główny dokument opozycji czeskiej.

Ludzie ci nie byli przy tym - w odróżnieniu od praskiego i brneńskiego środowiska dysydenckiego - opinion leaders czy opinion makers w swych miastach. Normalni mieszkańcy czeskich miast, nawet ludzie nastawieni antyreżimowo, o nich nie wiedzieli. Na przykład pierwszy po rewolucji starosta miasta Klatovy (zachodnie Czechy, 25 ooo mieszkańców), inż. Jan Vrána zwięźle stwierdził: „Dysydenci? Może tu byli, ale 99\% ludzi o nich nie wiedziało" $^{29}$. Także wpływowa postać w środowisku kulturalnym miasta Klatovy, prawnik Jiř́i Bílek, przez dłuższy czas prześladowany za przekonania religijne, odpowiedział bardzo podobnie: „Dysydenci? Nic nie wiem”30.

28 ÚSD, COH, zbiór Rozhovory. Rozmowę z Janem Thomą przeprowadziła Petra Trypesová, Pilzno 10 III 2004 r.

29 Archiwum autora. Rozmowę z inż. Janem Vránou przeprowadził Lukáš Valeš, Klatovy 11 XII $2001 \mathrm{r}$.

30 Archiwum autora. Rozmowę z prawnikiem Jiřím Bílkem przeprowadził Lukáš Valeš, Klatovy 22 XII $2001 \mathrm{r}$. 
Ten typ człowieka nie był - szczególnie w średnich i mniejszych miastach czeskich - akceptowany. Charakter miast czeskich był i pozostał konserwatywny (i bez przesady możemy powiedzieć - małomiasteczkowy) ${ }^{31}$, oparty na sieci powiązań personalnych, dbałości o „dobre imię rodziny”, intensywnej wzajemnej wymianie informacji o zachowaniu mieszkańców miasta. Powszechna, zwłaszcza wśród starszych mieszkańców, była niechęć wobec ludzi, którzy żyli (lub przynajmniej starali się żyć) inaczej. To odsuwało ich - nawet bez presji politycznej ze strony organów władzy - na margines społeczności. Co więcej, podpisanie Karty 77 było ich decyzją jednorazową, która nie musiała oznaczać początku działalności opozycyjnej. Grupa ta nie stała się więc, z powodów wyżej wspomnianych, decydującą dla przebiegu rewolucji 1989 r. w regionach. Jeden z przywódców rewolucji w mieście Klatovy, inż. Michal Kučera, tak scharakteryzował „niezależnych rewolucjonistów”: „Byli to ludzie na marginesie społeczności. Wykształceni, niby zwyczajni, ale moralnie zintegrowani. Byli honorowi, nie podporządkowali się reżimowi. Typy nie do zaakceptowania przez przeciętnych mieszkańców małego miasteczka. Byli rebeliantami w każdej sytuacji ${ }^{32}$. Ich znaczenie dla odzyskania wolności było jednak bezsporne. Byli to co prawda ludzie, którzy nie respektowali "zasad zachowania porządnych ludzi”, ale właśnie dlatego nie obawiali się ewentualnych reperkusji swobodnych - i politycznych - wystąpień. Brali oni często udział w powstaniu Forum Obywatelskiego (Občanské fórum) i w organizacji pierwszych listopadowych demonstracji.

Drugą, najważniejszą w początkowej fazie działań rewolucyjnych grupą byli ludzie, którzy stali na granicy między światem dysydentów a światem „normalnym”. Często poświęcali się działalności poza oficjalnym systemem (organizacja koncertów grup rockowych, folkowych i undergroundowych, przepisywanie książek autorów prześladowanych przez system, dystrybucja

31 Zob. także: L. Valeš, The political climate of the Czech town Klatovy, [w:] L. Cabada, Contemporary Questions of Central European Politics, Dobrá Voda 2002, s. 136-142; H. Jeřábek et al., Utváření postojů obyvatel českého města, I. - pracovní texty, Praga 1999; Z. Vajdová, Politická kultura lokálních politických elit: srovnání českého a východonèmeckého města - pracovní texty, Praga 1997.

32 Archiwum autora. Rozmowę z inż. Michałem Kučerą przeprowadził Lukáš Valeš, Klatovy 15 II $2002 \mathrm{r}$. 
nielegalnych publikacji opozycyjnych itp.) i mieli kontakty w praskim środowisku dysydenckim. Sami jednak nie podpisywali żadnych antyreżimowych dokumentów (w każdym razie tych głównych), nie byli intensywnie - albo w ogóle - prześladowani przez służbę bezpieczeństwa. Niektórzy $\mathrm{z}$ nich $\mathrm{w}$ końcu lat 80. brali udział w demonstracjach antyreżimowych, a przede wszystkim w kulturalnych, ekologicznych i innych obywatelskich akcjach wszelkiego rodzaju. Ludzie ci na poziomie lokalnym i regionalnym poruszali się gdzieś na pograniczu między dysydentami w klasycznym rozumieniu, z którymi łączy ich organizacja niedozwolonych, przede wszystkim kulturalnych, akcji albo na przykład udział w demonstracjach, a tzw. „szarymi”, zwykłymi obywatelami, którzy nie uczestniczyli w działalności opozycyjnej, chociaż w przeważającej większości nie zgadzali się z reżimem. Z tymi ostatnimi łączyło ich miejsce w społeczeństwie, to, że pochodzili w większości z rodzin klasy średniej, znanych w mieście, często były to osoby, których rodzice „coś znaczyli” w mieście, mieli więc poczucie swego rodzaju wpływów. Szczególnie w mniejszych miastach mimo swojej odmienności pozostawali integralną częścią struktury społecznej ze względu na związki rodzinne, przyjacielskie, oraz kolegów ze szkoły i z pracy itd. Ten fakt jest bardzo ważny. Działalność tych ludzi nie wyrwała ich ze zwykłego środowiska społecznego, nie stracili kontaktu z „normalnym światem”. W odróżnieniu od „klasycznych” czeskich dysydentów, takich jak Václav Havel czy przedstawicieli pierwszej grupy, nie żyli programowo w swego rodzaju getcie. Przeciwnie. To z jednej strony umożliwiało im wpływanie na otoczenie poprzez idee, poglądy itd., ale przede wszystkim, jako znani ze swoich „nonkonformistycznych działań”, stali się w Listopadzie 1989 r. główną "siłą napędową" rewolucji w swoich miastach i byli powszechnie akceptowani jako jej przywódcy, szczególnie na początku. Zachowanie integracji społecznej odróżniało ich od pierwszej grupy, chociaż i oni przez swoje poglądy, ale także na przykład ze względu na wygląd, zdecydowanie nie spełniali kryteriów „porządnych ludzi” (długie włosy, niedbała elegancja itd.) w małych i średnich miastach i nie byli elementem kultury społecznej małego miasta. To właśnie oni brali udział w formowaniu społeczeństwa obywatelskiego przed Listopadem 1989, w utrzymaniu pewnego stopnia świadomości i tradycji demokratycznych. Byli także pierwszymi, którzy organizowali antykomunistyczne demonstracje i którzy zakładali, jeszcze przy znacznym stopniu ryzyka, Fora Obywatelskie w regionach. Ważne było także, że chodziło tu o ludzi młodych, którzy nie doświadczyli traumy pokolenia 1968 r. (inwazji wojsk państw Układu Warszawskiego, 
likwidacji Praskiej Wiosny) i represji. Od pierwszej grupy odróżniała ich także pozytywna aktywność twórcza. Cytując Ericha Fromma, rebeliantom chodziło o wolność „od”, chcieli się wyswobodzić z norm społecznych, konwencji itd. Przedstawicielom drugiej grupy chodziło o wolność „do”. Także ta grupa nie miała początkowo celów politycznych. Motywacją ich działania było pragnienie pełnej życiowej realizacji, spełnienia osobistych planów i marzeń (nastawienie pozytywne) i wolności twórczej, w realizacji czego przeszkadzał im reżim komunistyczny. Dlatego powstali przeciw niemu. Ważnym motywem ich działania były kwestie etyczne: „To była zwykła ludzka postawa - nie świadomość celu, nie cel, styl życia. Nawet w Listopadzie - nie chcieliśmy robić rewolucji. Bolszewik był zaprzedanym oszustem - nie chcieliśmy mieć z nim nic wspólnego" ${ }^{\text {"3 }}$. Kolejnym ważnym motywem była potrzeba wspólnego działania, stworzenia własnego środowiska społecznego, w którym nie chodziłoby tylko o spotkanie ludzi o podobnych poglądach, ale o ich wspólną aktywność. Przez te działania często wchodzili w konflikt z reżimem. Jeden z pilzneńskich aktywistów, Petr Náhlík, tak wspomina początek swojej „kariery dysydenckiej”: „...zacząłem jeździć na rajdy. Tak dochodzę do tego, jak człowiek zaczął zajmować się polityką; stworzyliśmy ekipę, która nie jeździła jakoś do »hospody«, ale naprawdę jeździła do lasu, a przy okazji zaczęła się tworzyć jakaś subkultura, która wydawała tu w Pilznie czasopismo »Pajda«; zaczęliśmy spotykać się z ludźmi, którzy wydawali podobne czasopisma w całej republice, po prostu spotykaliśmy się na rajdach, spotykaliśmy się na różnych koncertach. Po prostu była to cała subkultura czasopism trampów ${ }^{34}$ mniej lub bardziej kulturalnych... Ci ludzie spotykali się, wysyłali sobie po prostu nawzajem teksty, dla niektórych czasopism powstawały jakieś poboczne redakcje, które dostawały jeden numer i przepisywały go dziesięć razy. Na tej samej zasadzie robiliśmy to czasopismo tu w Pilznie, zaczynało się z nakładem może 20 egzemplarzy, a kiedy już kończyliśmy, mieliśmy nakład prawie $100 . .$. i to tak działało w Pilznie od roku 80 do wiosny 82, wtedy skończyliśmy po interwencji

33 Archiwum autora. Rozmowę z Karlem Jungwirthem przeprowadził Lukáš Valeš, Klatovy 3 II 2002 r.

34 Czes. trampské časopisy - słowem „tramp” określano w Czechosłowacji turystę, który wyłamywał się z systemu oficjalnej, organizowanej przez państwo turystyki. Wokół tego zjawiska rozwinęła się cała „trampská kultura”, która stała się ważnym elementem czeskiej kultury nieoficjalnej i dla wielu przyszłych opozycjonistów była szkołą obywatelskiego nieposłuszeństwa - przyp. tłum. 
182 StB, która nas szeroko przesłuchiwała... Ale jak już byliśmy ciągani na te przesłuchania itd., to pojechaliśmy się podszkolić do tych naszych kolegów, o których wiedzieliśmy, że mają jakieś polityczne doświadczenie, no, to był przede wszystkim Pavel, zwany Česílko, on wprawdzie nie był sygnatariuszem Karty, ale jakoś się w tych kręgach obracał, no i Jarmila Štogrová, która nawet wydała, to była chartristka, więc ona wydała podręcznik, który nazywał się »Tramping i przepisy prawa«, gdzie właściwie wyjaśniała, co policja może, a czego nie może i to były interesujące informacje typu, że za rozniecenie ognia może być ukarany tylko ten, kto go rozniecił, przy czym policjant musi udowodnić, kto go rozniecił, dorzucanie do ognia nie jest karane, o ile człowiek powiedział, że już płonął, a podobne rzeczy były też z publikacjami. No więc my na przesłuchania chodziliśmy już przeszkoleni, co jakoś tych policjantów dosyć wkurzało, bo jak im tam człowiek powiedział, że odmawia odpowiedzi, bo by zaszkodził swoim bliskim, to oni oczywiście mówili, że osoba bliska to są tylko członkowie rodziny itd. Mnie wtedy ta pierwsza fala przesłuchań ominęła. Niezależnie od tego do tego gościńca Pod Złotą Kulą, gdzie chodziliśmy, chodzili też już ludzie tacy, jak na przykład Miroslav Svoboda, który już wtedy przynosił nam polityczne samizdaty. Ja wtedy niewiele $\mathrm{z}$ tego rozumiałem. Kiedy mi przyniósł jakąś samizdatową książeczkę z informacją, że to przepisała jakaś tam Olga Havlová, to w ogóle nie wiedziałem, o co chodzi, ale już człowiek trochę tego powąchał. A jak jeździliśmy do Pragi nauczyć się, jak się zachowywać na tych przesłuchaniach, to mówiliśmy sobie, no dobra, jak już nas ci policjanci gnębią dlatego, że robimy zupełnie niewinną twórczość naszych kolegów, która jest po prostu apolityczna, to jeżeli mamy coś przepisywać, to powinniśmy przepisywać coś porządnego..." ${ }^{35}$.

Ważnym motywem zaangażowania tej grupy w życie publiczne było chrześcijaństwo i związek z Kościołem katolickim, a może przede wszystkim z Kościołami ewangelickimi.

Dla tej grupy było charakterystyczne, że - poza kilkoma wyjątkami - po tym, jak padł reżim komunistyczny, odsunęli się także od nowej, demokratycznej polityki i poświęcili się znowu swojej działalności obywatelskiej (ale także na przykład biznesowej, artystycznej itd.).

35 ÚSD, COH, zbiór Rozhovory. Rozmowę z inż. Petrem Náhlíkem przeprowadził Lukáš Valeš, Pilzno 11 XII 2003 r. 
Trzecią grupę stanowią uczniowie szkół średnich, a przede wszystkim studenci. Szczególnie w drugiej połowie lat 8o. szkoły wyższe zaczęły znowu stawać się miejscem relatywnie swobodnych dyskusji - czy to bezpośrednio na gruncie akademickim, czy też (i to głównie) w klubach studenckich, w akademikach itd. W tym właśnie środowisku kolportowano polityczne i niepolityczne samizdaty, odbywały się koncerty dotychczas zakazanych autorów i grup (Jarek Nohavica) itp. Studenci, którzy w większości mieszkali poza miastem, w którym studiowali, te „produkty działalności opozycyjnej”, informacje, nagrania z koncertów itd. dystrybuowali później w miejscach swego zamieszkania, w większości w mniejszych miastach, w tym miasteczkach okręgowych i na wsiach. W ten sposób powstał ważny kanał przekazywania informacji o opozycji w Czechosłowacji do miejsc, gdzie w inny sposób nie byłoby to możliwe. Jednocześnie część studentów wchodziła w konflikty z władzą albo z powodu swojej działalności kulturalnej w miejscu studiów (takiej jak na przykład organizacja dyskotek), albo ze względu na zaangażowanie w miejscu zamieszkania (aktywista z Klatov Michal Kučera został relegowany z pilzneńskiej Wyższej Szkoły Maszynowej i Elektrotechnicznej za to, że w wynajętej przez siebie restauracji organizował koncerty grup punkowych i rockowych) ${ }^{36}$. To właśnie studenci przynieśli do swoich miast i regionów prawdziwe i nieocenzurowane informacje o brutalnej interwencji służby bezpieczeństwa 17 listopada $1989 \mathrm{r}$. Studenci praskich uczelni w kolejnych dniach listopada i grudnia 1989 r. jeździli wraz z ludźmi teatru na czeską prowincję, występowali na lokalnych manifestacjach i informowali miejscową ludność o wydarzeniach w stolicy (a także dystrybuowali druki Forum Obywatelskiego, informacje o Václavie Havlu itd.).

Czwartą grupę tworzą więźniowie polityczni z lat 50., a więc z okresu najostrzejszego stalinizmu w Czechosłowacji, epoki, którą bez przesady możemy nazwać totalitarną. W okresie tzw. normalizacji (1969-1989) ich udział w działalności dysydenckiej na poziomie lokalnym czy regionalnym był relatywnie niski, więc w działalności antyreżimowej rzadko znajdziemy przedstawicieli tego pokolenia. Była to do pewnego stopnia kwestia pokoleniowa.

36 Archiwum autora. Rozmowę z inż. Michałem Kučerą przeprowadził Lukáš Valeš, Klatovy 15 II 2002 r. Właśnie Michal Kučera i jego żona Jana są dowodem, że między poszczególnymi grupami nie istnieje jednoznaczna granica - tego samego człowieka można przypisać do kilku grup. Chodzi raczej o ogólną systematyzację. 
184 Więźniowie z lat 50., którzy w przytłaczającej większości zostali skazani na długoletnie roboty przymusowe w procesach pokazowych nie chcieli zapewne wystawiać siebie i swoich bliskich na niebezpieczeństwo kolejnych represji ze strony władz. „...jedynym, który się tam naprawdę bał, był mój szef zmiany, który nazywał się Josef Březina i pochodził z okolic Szumperka. Kiedy miał 18 lat, został skazany na dwadzieścia lat za to, że podpalił swoje rodzinne gospodarstwo w chwili, gdy im je przyszli kolektywizować, on odsiedział ponad 10 lat i czekał go tylko ten tradycyjny los więźniów w kopalni uranu w okolicach miasta Přibram. Tam pracowali ludzie, którzy byli wrodzy reżimowi i którzy byli tam z powodów ekonomicznych, bo oni tak naprawdę nie mieli szansy na jakąkolwiek karierę zawodową, a praca w kopalniach uranu z drugiej strony zapewniała im bardzo przyzwoity poziom życia, jeżeli zostali. Więc Josef Březina był jednym z tych, którzy zostali, przeszedł przez Wojnę i Bytiz ${ }^{37}$ i właśnie to doświadczenie go uformowało, że w przeciwieństwie do innych ludzi, których poznałem jako więźniów politycznych, on bał się, bo on się potem ożenił, miał dwoje dzieci i bał się, że w jakiś sposób znowu by się dostał na tę karuzelę. Więc kiedy rano ktoś włączał Głos Ameryki albo Londyn, to on odchodził z warsztatu i wracał dopiero, kiedy to radio wyłączali, bo znał praktyki systemu czy tam reżimu i wiedział, że jeżeli chcieliby uderzyć, to by uderzyli i że by się nim nie patyczkowali"38. Z drugiej strony niektórzy $\mathrm{z}$ nich angażowali się nawet w czasie normalizacji. Wielu z nich znajdziemy zwłaszcza wśród dysydentów morawskich (S. Lekavy, J. Krumpholz), także Josef Thoma z Pilzna itd. Właśnie ta aktywna grupa, dosyć nieliczna, ale jak na swój wiek nadal żywotna, stanowiła zdecydowane wzmocnienie dla nowo powstających lokalnych i okręgowych Forów Obywatelskich. W odróżnieniu od „podekscytowanych” młodych ludzi, mieli oni moralny i zawodowy autorytet, wzmocniony znacznym doświadczeniem życiowym, na którym mogli się oprzeć członkowie drugiej grupy. Część z nich krótko po listopadzie 1989 r. było wybranych czy mianowanych na stanowiska kierownicze w organach lokalnej, okręgowej i krajskiej administracji publicznej (na przykład doktor Olbrich Richter z miasta Klatovy został wiceprzewodniczącym tamtejszej okręgowej rady narodowej itd.).

37 Obozy pracy przymusowej w Czechosłowacji, na które często skazywani byli więźniowie polityczni - przyp. aut.

38 ÚSD, COH, zbiór Rozhovory. Rozmowę z Josefem Vackem przeprowadziła Jana Melicharová, Př́bram, 5 VI 2003 r. 
Piątą grupą jest tzw. pokolenie '68. Grupę tę rozumiemy szerzej niż tylko jako przedstawicieli skrzydła reformatorskiego w Komunistycznej Partii Czechosłowacji w 1968 r., którzy po inwazji wojsk Układu Warszawskiego byli prześladowani za swoje poglądy polityczne. Generalnie chodzi o ludzi, których pierwsze, a w każdym razie najważniejsze doświadczenie w polityce w jakiś sposób wiąże się z 1968 r. - ci, którzy w '68 roku zakładali KAN, ówcześni studenci, którzy organizowali tzw. „majalesy” [majówki studenckie, odpowiednik polskich juwenaliów - przyp. tłum.] i strajki przeciw okupacji i oczywiście byli komuniści, którzy faktycznie brali udział w kształtowaniu „Praskiej Wiosny”. Nawet tę podgrupę trzeba podzielić. Należą do niej wysoko postawieni komuniści z 1968 r., ówczesne doły partyjne, ale także pracownicy administracji państwowej, dziennikarze itd. Część z nich po 1989 r. stworzyła wpływową organizację OBRODA [odrodzenie - przyp. tłum.], której celem było wskrzeszenie ideałów Praskiej Wiosny. Ogólnie wkładem tej grupy w rewolucję w listopadzie 1989 r. na poziomie lokalnym i regionalnym było ich polityczne doświadczenie i zdecydowanie najlepsza znajomość meandrów politycznych, w tym porządku prawnego, działania urzędów czy mechanizmów funkcjonowania krajskich, miejskich i lokalnych rad narodowych. Były to informacje i umiejętności nie do przecenienia w czasie, kiedy rewolucję robili ludzie może zapaleni i - w większości - moralnie bez zastrzeżeń, ale także bez jakiejkolwiek znajomości państwowych mechanizmów władzy. Byli komuniści z 1968 r. - poza wyjątkami - niezbyt długo pozostali w polityce lokalnej i regionalnej. Mimo to, dzięki swoim umiejętnościom i doświadczeniu politycznemu, przyczynili się do gładkiego i bezproblemowego przejęcia władzy przez nowe elity demokratyczne na poziomie krajskim, okręgowym i lokalnym, bez zakłócenia normalnego działania administracji publicznej.

Szóstą grupę stanowią członkowie tolerowanych przez dotychczasowy reżim partii politycznych (Chrześcijańska Czechosłowacka Partia Ludowa i Czechosłowacka Partia Socjalistyczna) i organizacji, które były przymusowo włączone w struktury tzw. Frontu Narodowego. Władze Frontu Narodowego były niemal w całości obsadzone przez członków KPCz i w ten sposób reżim komunistyczny sprawował bezpośrednią i pośrednią kontrolę nad wszystkimi organizacjami w kraju, w tym nad związkami zawodowymi, związkiem kobiet, stowarzyszeniami branżowymi, ale także nad organizacjami, takimi jak związek działkowców czy klub automobilowy. Tu właśnie możemy spotkać ludzi, którzy - skrycie lub jawnie - jeszcze w czasie rządów reżimu komunistycznego wyrażali niezadowolenie i krytykę. Ciekawym zjawiskiem było 
przenikanie członków struktur opozycyjnych właśnie do organizacji partii ludowej czy socjalistycznej. Chociaż partie te były integralną częścią struktur reżimowych, stanowiły jednocześnie jedyną legalną platformę „polityki niekomunistycznej”. Bardziej postępowa część członków dotychczasowych partii niekomunistycznych wyraziła pełne poparcie dla ruchu opozycyjnego i na poziomie lokalnym przeprowadziła „odrodzenie” swoich partii. Ich wielką zaletą było to, że mieli do dyspozycji działające sekretariaty partyjne i co za tym idzie tak bardzo potrzebne lokale, a także doświadczenie polityczne, które mogli teraz zaoferować rodzącej się właśnie opozycji.

Siódmą grupą są lokalne elity społeczne - liderzy opinii. Chodzi tu o uznane autorytety - moralne czy zawodowe - danego miasta lub gminy, ludzi, którzy piastowali prestiżowe funkcje czy wykonywali prestiżowe zawody i mieli wyższe wykształcenie. Do tej kategorii zaliczymy lekarzy, nauczycieli, prawników czy duchownych. W swoich miastach cieszyli się oni powszechnym szacunkiem i ze względu na swoją pozycję społeczną i ponadstandardowe wykształcenie byli elitą miasta. Ze względu na swoją pozycję nie mogli się dotąd angażować w żadną działalność opozycyjną - ich pozycja w dużym stopniu zależała także od pewnego konformizmu wobec reżimu. Ich sympatia była jednak jednoznacznie po stronie grup antyreżimowych - także dlatego, że grupa ta była głęboko świadoma narastających problemów systemu. Owe elity lokalne uważnie śledziły obiecujący rozwój sytuacji w Związku Radzieckim czasów Michaiła Gorbaczowa, a także sytuację w sąsiednich krajach socjalistycznych, gdzie stopniowo dochodziło do destrukcji władzy komunistycznej. Właśnie oni potrafili, dzięki swemu autorytetowi i znajomościom w danym mieście - pozyskać dotychczas niezdecydowanych współobywateli dla ruchu opozycyjnego w listopadzie 1989 r. Wielu członków lokalnych elit włączyło się bezpośrednio w organizację manifestacji i prac Forum Obywatelskiego, lub zakładało w swoich miastach i regionach komórki nowych partii politycznych. Najaktywniejsi politycznie byli przede wszystkim lekarze, prawnicy (adwokaci) i nauczyciele, a więc przedstawiciele zawodów szanowanych w czeskich miastach i gminach, które ze względu na swój charakter (stały kontakt z ludźmi, poczucie znaczenia społecznego i sukcesu życiowego w oczach opinii publicznej) były w dużym stopniu "publiczne” i których przedstawiciele byli (i nadal są) blisko lokalnej polityki. Ludzie ci stanowili naturalny rezerwuar nowych elit politycznych.

Ósmą grupę stanowią pracownicy przedsiębiorstw. Podczas gdy najwyższe kierownictwo czechosłowackich zakładów było wybierane na podstawie dokładnych zleceń politycznych, a jego członkowie należeli do 
„sprawdzonej kadry”, średnia i niższa kadra zarządzająca musiała przede wszystkim spełniać kryteria profesjonalne. Właśnie ci ludzie, wśród nich często także zwykli pracownicy (i robotnicy), w swoich zakładach rozprowadzali informacje o wydarzeniach w Pradze, zakładali Fora Obywatelskie, negocjowali z kierownictwem postulaty polityczne, a przede wszystkim organizowali strajk generalny 27 listopada 1989 r. Właśnie fakt, że udało się go zorganizować i że przyłączyły się do niego praktycznie wszystkie przedsiębiorstwa w Czechosłowacji, przesądził o sukcesie rewolucji. W odróżnieniu od wcześniejszych działań opozycji, tę akcję poparły wszystkie warstwy społeczne - w tym robotnicy, którzy zgodnie z ideologią komunistyczną mieli stanowić główne oparcie reżimu, a także wszystkie regiony kraju. Znaczenie przedsiębiorstw i postawy politycznej ich pracowników było decydujące przede wszystkim w tych miastach, gdzie jedno lub najwyżej kilka przedsiębiorstw przesądzało o lokalnej sytuacji ekonomicznej (zatrudniały zdecydowaną większość mieszkańców) - na przykład Škoda Pilzno, ČKD v Pradze, Škoda Auto Mladá Boleslav itd. Między opozycją a członkami i kierownictwem lokalnych organizacji partyjnych toczyła się wręcz „walka o zakłady", którą partia komunistyczna przegrała. Było to spowodowane między innymi także szczególną przestrzenią wolności, jaka panowała w tym środowisku, uważanym przez reżim ze „sprzymierzeńca”, więc organy służby bezpieczeństwa nie poświęcały mu - w przeciwieństwie np. do uniwersytetów - szczególnej uwagi. Václav Burian z Ołomuńca, przedstawiciel drugiej grupy, pracował w ołomunieckiej fabryce farmakologicznej Farmazon: „...w tym Farmazonie było całkiem oczywiste, że kiedy o tej szóstej rano robiliśmy sobie kawę, to najpierw przegadaliśmy to, co wczoraj powiedziała Wolna Europa, co mówił Głos Ameryki, w ogóle nie patrzyliśmy na to, czy ktoś z kolegów jest na przykład członkiem partii czy coś. Więc powiedziałbym, że był to światek dość płodny i właściwie to stamtąd mam do dzisiaj dużo przyjaciół" ${ }^{39}$. Podobne doświadczenie ma Josef Vacek z miasta Př́bram: „Ważnym doświadczeniem życiowym było przejście na kopalnię $\mathrm{w}$ trzecim roku nauki..., no to było naprawdę zderzenie z prawdziwym życiem... To mnie strasznie zafascynowało, że w szkole nas uczyli, jak to klasa robotnicza jest podporą systemu socjalistycznego, a kiedy przyszedłem na kopalnię, to zobaczyłem, że to nie jest prawda, że właśnie robotnicy są być

39 ÚSD, COH, zbiór Rozhovory. Rozmowę z Václavem Burianem przeprowadził Pavel Urbášek, Ołomuniec 22 XI 2002 r. 
może najmniej zadowoloną grupą społeczną, a takie nazwijmy to szkolenie polityczne odbywało się z jednej strony przez przekazywanie doświadczeń starszych pracowników, którzy przez to, że pracowali w kopalniach uranu, mieli codzienny kontakt z więźniami politycznymi, którzy stanowili bardzo znaczny procent pracowników w latach 50. i 60. i jeszcze zwróciło moją uwagę, że każdego ranka między szóstą a siódmą za socjalizmu nic się nie robiło. Rano przychodziły gazety i komentowało się wstępniaki i wyrzekało się na bolszewika. Dla mnie to było naprawdę zaskoczenie, że po szóstej nastawiano Głos Ameryki i bezpośrednio w warsztacie normalnie cały warsztat na głos słuchał Głosu Ameryki, albo słuchaliśmy często BBC, z Londynu. Ciekawe, że to było jakoś tolerowane... To właśnie kontakt z pracownikami i powiedzmy regularne słuchanie zagranicznego radia zmusiły mnie z czasem do zastanowienia się nad systemem, w którym żyjemy i dlatego że dla tych ludzi ciągle bardzo silnym przeżyciem był 1968 r. i późniejsza okupacja. Zaczęły mnie interesować losy konkretnych ludzi, którzy pracowali obok mnie, to, jak przeżywali okupację, jak przeżywali potem normalizację, którą właśnie w tamtym okresie zacząłem oceniać jako bardzo duże bezprawie. Chyba w ciągu kilku miesięcy, to była sprawa pół roku, jak stałem się regularnym słuchaczem Wolnej Europy... Także właśnie słuchanie zagranicznego radia, kontakt ze współpracownikami, którzy powiedzmy nie byli zbytnio zachwyceni systemem normalizacyjnym, który tutaj istniał, to mnie przeciągnęło na drugą stronę. Jest faktem, że czasem dopadała mnie beznadzieja, kiedy uświadamiałem sobie, że właśnie w tym reżimie będę musiał przeżyć całe życie, że w jakiś sposób będę musiał się do niego przystosować, ale ustanowiłem sobie takie podstawowe zasady, że nigdy nie wstąpię do partii komunistycznej i że, o ile się uda, nie będę nawet w komunistycznych związkach zawodowych"40.

Chociaż mowa tu o lokalnych środowiskach dysydenckich, także tu ważną rolę odgrywała Praga, przynajmniej jeżeli chodzi o terytorium samych Czech. Praga jest dla Czechów miejscem wyjątkowym - jako jedyne w swoim rodzaju centrum geograficzne, polityczne i kulturalne o wielkiej sile przyciągania. Dla ludzi z regionów, a przede wszystkim ze średnich i mniejszych miast, także w czasie niewoli oznaczała przestrzeń wolności o wiele większą niż ta, do jakiej przywykli - zarówno dzięki niezależnemu duchowi

40 ÚSD, COH, zbiór Rozhovory. Rozmowa z Josefem Vackem przeprowadziła Jana Melicharová, Příbram 5 VI 2003 r. 
Pragi nawet w okresie normalizacji, jak i - co nie bez znaczenia - dzięki jej anonimowości i niezależności od rodzimego środowiska. W swoich rodzinnych miastach ludzie byli pod staranną obserwacją - ze strony organów politycznych, służby bezpieczeństwa i swoich współobywateli. W Pradze znajdowali pokrewne dusze. Praga była także niemal jedynym - z wyjątkiem uzdrowisk - miejscem, gdzie społeczeństwo czeskie także w okresie niewoli miało kontakt z „obcymi kapitalistami”, czy to bezpośrednio, szczególnie przez zagranicznych gości, czy pośrednio poprzez zagraniczne towary. To wszystko wzbudzało w przybyszach spoza Pragi poczucie swobodniejszej atmosfery, czy przynajmniej jej złudzenie (i nie chodzi tu jedynie o poczucie wolności w politycznym sensie, ważniejszy jest jego ogólny, ludzki wymiar). Praga przyciągała także swoją względną nowoczesnością - od architektury, przez komunikację aż po wprowadzane tu nowocześniejsze technologie, na przykład techniki komputerowe. Relacje między regionami a centrum celnie podsumował jeden z przedstawicieli Forum Obywatelskiego w Klatovach i były burmistrz [czes. starosta] miasta Karel Mráz: „To, co jest w Pradze oczywiste, a w Pilznie dozwolone, w Klatovach jest zdecydowanie zakazane... Ten, kto tu mieszkał, każdego dnia doświadczał tej prawdy. Ludzie z politycznymi grzeszkami na sumieniu woleli przeprowadzić się do Pragi, żeby ich dzieci dostały się do szkoły średniej, wielu musiało szukać gdzie indziej zatrudnienia zgodnego z kwalifikacjami, o którym w domu nie mogliby nawet pomyśleć. Jeszcze w epoce pierestrojki w Klatovach przestrzegano wszystkich wyznaczonych rytuałów, takich jak szkolenia partyjne, demonstracje politycznej lojalności na zamówienie, oficjalne obchody. Nie ma przy tym wątpliwości, że ten demonstracyjny chocholi taniec było wyćwiczoną, mechaniczną zasłoną dymną, za którą istniała powszechna zgoda co do tego, że reżim jest na wykończeniu, że jest sam"41.

Istotnym elementem w życiu ludzi z grupy pierwszej i drugiej, była kultura, a szczególnie muzyka. W reżimach autorytarnych jakakolwiek aktywność kulturalna jest podejrzana - szczególnie ta, która balansuje na granicy wyznaczonej przez reżim. Sama działalność artystyczna jest przecież najczystszym przejawem ludzkiej wolności. Przywołując słowa najważniejszego czeskiego dysydenta, także artysty Václava Havla: „W okresach braku wolności, kiedy władza wymusza lojalność obywateli, czy przynajmniej ich milczenie, kultura wystawiana bywa na szczególnie ciężkie próby. Jeżeli

41 L. Valeš, Listopad 89 v Klatovech..., s. 7. 
stawia opór, jest prześladowana i tępiona, jeżeli ulegnie, zaprzecza sobie samej. Bez wolności nie może istnieć, o ile chce być czymś więcej niż tylko skazanym na zapomnienie odbiciem stylu swojej epoki" ${ }^{42}$. Dysydent, a po rewolucji burmistrz miasta Př́bram (środkowe Czechy) Josef Vacek mówi: „...interesowała mnie muzyka rockowa i właściwie takie pierwsze podświadome konflikty z systemem wynikały z tego, że odrzucał muzykę, którą lubiłem, albo w bardzo skomplikowany sposób docierałem do kapel rockowych, które mi się podobały, Rolling Stones, Boba Dylana, nie mogłem zrozumieć, dlaczego ówczesnym ideologom ta muzyka przeszkadza"43.

Drugą ważną sferą życia, która, chociaż początkowo apolityczna, była także przyczyną represji i co za tym idzie jednym z powodów, dla których wielu ludzi wzięło udział w działalności antyreżimowej przed listopadem 1989 i podczas Aksamitnej Rewolucji, było chrześcijaństwo: „W tamtym okresie zacząłem już bardzo intensywnie flirtować z chrześcijaństwem, bo właśnie Plastik People ${ }^{44}$, to był gdzieś rok '78, '79, napisali muzykę do pasji i nagle po raz pierwszy w życiu była to dla mnie zrozumiała forma objawienia, forma, która była mi bliska. Ta muzyka rockowa, a do tego te cudowne pieśni z Sváti [Svatopluka - przyp. tłum.] Karáska, to były takie dwa pierwsze powody, które mi „dały kopa” w stronę chrześcijaństwa. Zacząłem się tym bardzo intensywnie interesować. Załatwiłem sobie Biblię, zacząłem jakoś tak spontanicznie czytać Stary i Nowy Testament, ale to jeszcze nie było definitywne zakończenie tej konwersji, które przyszło później, po wojsku. No więc jak szedłem do wojska, wziąłem ze sobą Nowy Testament... no i tam właśnie w powodu tego Nowego Testamentu ... jeden mój kumpel na mnie doniósł, więc właśnie tam po raz pierwszy miałem kontakt z organami kontrwywiadu wojskowego. I po raz pierwszy spotkało mnie to, czego ludzie, którzy pracowali w opozycji, doświadczali na własnej skórze. Na przykład wzywali mnie w nocy na przesłuchanie i zadawali mi różne pytania, ale ja byłem wtedy zupełnie ideologicznie zahartowany i wiedziałem, że nie chcę mieć z tym systemem nic wspólnego. A to konkretnie majora Zicha, który był szefem kontrwywiadu wojskowego w Volarach, strasznie prowokowało. Pamiętam, że przy moim nazwisku był taki wielki

42 V. Havel, Úvodní slovo, [w:] M. Vaněk, Byl to jenom rock'n'roll? Hudební alternativa v komunistickém Československu 1956-1989, Praha 2010, s. 9.

43 ÚSD, COH, zbiór Rozhovory. Rozmowę z Josefem Vackem przeprowadziła Jana Melicharová, Př́ibram 5 VI 2003 r.

44 Najważniejsza czeska muzyczna grupa awangardowa. 
wykrzyknik. Oczywiście potem te materiały szły do właściwego oddziału StB [służby bezpieczeństwa] w miejscu zamieszkania"45.

Na swej dysydenckiej drodze większość ludzi w pewnym okresie rozwoju stawała się wierząca - czy to indywidualnie, czy jako członkowie jakiegoś Kościoła (przede wszystkim ewangelickich czy katolickiego). W podejściu do chrześcijaństwa istnieją przy tym zasadnicze różnice na poszczególnych historycznych ziemiach czeskich. Mieszkańcy Moraw byli i są wychowywani w tradycji chrześcijańskiej czy katolickiej i ogromna część tutejszych dysydentów była bezpośrednio lub pośrednio związana z Kościołem katolickim. W wielu przypadkach możemy wręcz mówić o dysydentach katolickich ${ }^{46}$. Mieszkańcy Czech właściwych są natomiast przeważnie bez wyznania. Chrześcijaństwo nie jest tu ugruntowane w rodzinie i dlatego kontakt z wiarą jest późniejszy - narratorzy podają okres około dwudziestego roku życia, czasem nawet później. Ich droga do wiary była związana z procesem samouświadomienia i nie była tak prosta, jak w przypadku narratorów morawskich. Nierzadko właśnie po sakramencie chrztu czy innej formy przyjęcia chrześcijaństwa narratorzy wchodzili w konflikt z reżimem, który ze względu na ich wyznanie nakładał na nich niemałe sankcje. „Miałem na StB odsiedziane mnóstwo godzin, ale to było przeważnie z powodu Kościoła, bo dałem się ochrzcić chyba gdzieś w wieku dwudziestu czterech lat i miałem takiego fantastycznego proboszcza, który zaraz po rewolucji poszedł wykładać dogmaty i mistykę do Ołomuńca i on robił mi takie tajne komplety. On mnie sobie wybrał, chodziłem do niego na szachy, a w tym czasie on mnie uformował, naprawił" ${ }^{47}$.

Kolejnym ideowym źródłem inspiracji dla lokalnych dysydentów były lata 6o. Także w tym przypadku widać różnicę w pojmowaniu działalności dysydenckiej między regionami a oboma centrami. Dysydenci spoza Pragi nie odwołują się bezpośrednio do Praskiej Wiosny, roku '68 i jego skutków

45 ÚSD, COH, zbiór Rozhovory. Rozmowę z Josefem Vackem przeprowadziła Jana Melicharová, Př́ibram 5 VI 2003 r.

46 Zob. np.: ÚSD, COH, zbiór Rozhovory. Rozmowę z Ivou Kotrlou przeprowadziła Jana Nosková, Brno 24 I 2004 r.; ÚSD, COH, zbiór Rozhovory. Rozmowę ze Stanislavem Lekavým przeprowadził Tomáš Wiesner, Zlaté Hory 5 VIII 2003 r.; ÚSD, COH, zbiór Rozhovory. Rozmowę z Janem Šimsou przeprowadził Pavel Urbášek, Brno 20 XI 2003 r. Transkrypcje tych rozmów opublikowano w książce Vitězové? Poražení? Životopisná interview, red. M. Vaněk, P. Urbášek, t. 1, Praha 2005.

47 Archiwum autora. Rozmowę z Karlem Jungwirthem przeprowadził Lukáš Valeš, Klatovy 3 II 2002 r. 
192 politycznych. Lata sześćdziesiąte pojmują jako czas odwilży politycznej, ale przede wszystkim jako wspaniałą dynamiczną epokę, kiedy rozkwitała kultura, film, literatura i aktywność intelektualna, co stoi w wyraźnej opozycji do statycznych, bezczasowych lat 70. czy 80. Nie chodzi tu, podobnie jak w przypadku Pierwszej Republiki [Czechosłowackiej - przyp. tłum.], o osobiste doświadczenie - wielu spośród naszych narratorów zaczęło odkrywać ten okres jako odległy w czasie, na podstawie lektury ówczesnej literatury, filmów, a także gazet i czasopism, czy poprzez opowieści i spotkania z ludźmi, którzy ten etap przeżyli pod jakimś względem aktywnie (Ivan Klima), także z członkami rodziny. Właśnie przekazane przez nich doświadczenie lat 60. mogło mieć znaczący wpływ na ideowe i intelektualne uformowanie naszych narratorów. Jak mówi dysydent z Ołomuńca Václav Burian: „...myślę, że najwięcej dała mi mama. Razem z tymi stosami pism „Plamen”, „Literární nowiny”, ale i „Tvár”, „Orientace” itd., po prostu czasopismami z lat sześćdziesiątych, na których lekturze spędziłem lata siedemdziesiąte i osiemdziesiąte"48.

Podobnie Petr Náhlík z Pilzna: „...moje jakieś pierwotne poczucie, kiedy zacząłem nabierać rozumu, to zacząłem strasznie zazdrościć ludziom, którzy przeżyli sześćdziesiąty ósmy i w ogóle lata 6o., bo jak człowiek miał tych 15 lat i zaczynał myśleć o świecie, to miał wrażenie, dziś myślę tak samo, wrażenie jakiegoś bezczasu. Że po prostu nic się nie działo, stojąca woda i to tak sobie trwało aż do początku lat osiemdziesiątych, a dopiero na końcu lat 8o., szczególnie w pierwszych miesiącach po 17 listopada '89 czułem, że nawet gdyby to przetrwało tylko tych sześć tygodni od 17 listopada do wybrania Havla na prezydenta, to i tak warto by było. To pierwsze uczucie, kiedy człowiek żył w tych latach 70., myślę, że podobne wrażenie mogli mieć ludzie w latach 50., że właściwie wszystko zmierzało w stronę jakiegoś takiego bezczasu i donikąd, podczas gdy w latach 8o., tak już gdzieś pojawiało się jakieś takie światełko na końcu tunelu"49.

Kolejnym ważnym źródłem tradycji demokratycznych była epoka I Republiki [Czechosłowackiej - przyp. tłum.] (1918-1938), symbolizowana między innymi przez założyciela państwa czechosłowackiego Tomasza G. Masaryka. Wielu narratorów odwołuje się do tamtych czasów i uważa je - na

48 ÚSD, COH, zbiór Rozhovory. Rozmowę z Václavem Burianem przeprowadził Pavel Urbášek, Ołomuniec 22 XI 2002 r.

49 ÚSD, COH, zbiór Rozhovory. Rozmowę z inż. Petrem Náhlíkem przeprowadził Lukáš Valeš, Pilzno 11 XII 2003 r. 
podstawie opowieści członków rodziny, a także samodzielnych studiów za złotą epokę w czeskiej historii. Chociaż ten obraz I Republiki jest często wyidealizowany, w epoce reżimu komunistycznego idealizacja ta była bardzo potrzebna. Umacniała w naszych narratorach (i nie tylko w nich) świadomość, że naród, do którego należeli, jest nosicielem demokratycznych tradycji I Republiki Czechosłowackiej, podczas gdy czasy współczesne są ich zaprzeczeniem, a więc także zaprzeczeniem prawdziwej tożsamości Czechów - z punktu widzenia długofalowego rozwoju historycznego reżim komunistyczny jest w naszej historii ślepą uliczką. Znaczącym elementem była tu także kultura i twórczość artystyczna z epoki I Republiki, która umacniała pozytywne nastawienie naszych narratorów. Możliwe, że także wiarę, że te „stare dobre czasy” powrócą w nowym przebraniu. „Notowania" I Republiki były wysokie także dlatego, że z punktu widzenia człowieka z końca XX w. była to oaza spokoju i stabilności. Natomiast okres po jej końcu naznaczony był nieustannymi zmianami politycznymi i społecznymi. Co więcej, reżim komunistyczny starał się tę epokę historii czeskiej możliwie najbardziej oczernić:

„Z upływem czasu coraz bardziej interesowały mnie kwestie związane z historią, szczególnie zaczęła mnie interesować I Republika, o której myślałem, że był to na pewno czas, kiedy naszemu narodowi powodziło się relatywnie najlepiej i nagle poczułem, że to, co nam wmawiano o I Republice, o legionach, o systemie demokratycznym, który tutaj funkcjonował, że to wszystko jest ordynarne ciężkie kłamstwo. Pomogło mi w tym także to, że w tamtym okresie zacząłem się interesować literaturą, więc właśnie okres tych powiedzmy dwudziestu lat w sztuce I Republiki, definitywnie mnie przekonał, że system, w którym powstało tyle piękna w dziedzinie architektury, literatury, sztuk pięknych, nie mógł być zły"50.

Z drugiej strony większość narratorów zgadza się co do tego, że motywem czy wzorem dla ich działalności nie były stalinowskie lata 50. czy antykomunistyczny ruch oporu, więźniowie polityczni tamtych czasów itd., a więc okres, kiedy ludzie, uznani przez reżim za wrogów, byli skazywani na karę śmierci i na długoletnie roboty przymusowe - na przykład w kopalniach uranu. Fakt ten w pewnym stopniu burzy wyobrażenie o kontynuacji w działalności antykomunistycznej. Istnieją oczywiście ludzie,

50 ÚSD, COH, zbiór Rozhovory. Rozmowę z Janem Vackem przeprowadziła Jana Melicharová, Př́íbram 5 VI 2003 r. 
194 którzy angażowali się w obu okresach - zarówno w latach pięćdziesiątych, jak i w okresie normalizacji, są to jednak raczej wyjątki. Interesujący był także niedostatek wiedzy młodszych narratorów czy ludzi, którzy byli aktywnymi dysydentami w latach 70., a szczególnie 80., o tym, co właściwie działo się w latach 50.: „Ja nie wiedziałem zbyt dużo o latach pięćdziesiątych. Wiedziałem oczywiście, że to było wielkie świństwo, ale dopiero wtedy, kiedy po rewolucji zacząłem spotykać się z więźniami politycznymi z lat 50. Kiedy oni opowiadali te swoje historie, to szczęka mi opadała i uświadomiłem sobie, że to, co my robiliśmy, to była normalna postawa obywatelska, ale nikt już cię nie prześladował, poza jakimiś przesłuchaniami, nie groziliby mi, byłem urzędnikiem, to mogli mnie zdegradować na robotnika. Ja na przykład nie chodziłem nawet na wybory, co było dla nich nie do przyjęcia... Prawdę mówiąc przez to pierwszy raz siedziałem na policji, to było okropne uczucie, ale nigdy nie doświadczyłem żadnej przemocy fizycznej, psychicznej, no psychiczną może tak, ale kiedy już zrozumiesz, o co chodzi i się nastawisz na tę atmosferę, to da się to wytrzymać. Wielu ludzi robi z tego jakieś zasługi, ale przecież te lata osiemdziesiąte to był taki folklor, jeszcze może coś do jakiegoś ' 83 było, ale od tego czasu, jak przyszedł Gorbaczow, to już nie" ${ }^{n 1}$.

Interesujące świadectwo o naturze działalności dysydenckiej na poziomie lokalnym, a jednocześnie swego rodzaju podsumowanie tej problematyki w okresie przed listopadem daje pilzneński dysydent, a po listopadzie 1989 r. wiceprezydent Pilzna Petr Nahlík: „Myślę, że tutaj było bardzo mało ludzi, którzy pierwotnie traktowali walkę z reżimem jako polityczny bój, chociaż faktycznie było tu kilku sygnatariuszy Karty 77, ale i tych można podzielić na tych, którzy podpisali ją jako jeden z protestów lat 70., nie zdając sobie sprawy, co właściwie podpisują, jakie znaczenie to będzie mieć w przyszłości i na tych, którzy przyłączyli się do Karty, wiedząc, na co się decydują, jakie mogą ich spotkać represje itd. Więc część z tych ludzi traktowała to od początku jako walkę polityczną, a część nie. I znów to szło w poprzek pokoleń. Następnie jest tu o wiele większa grupa ludzi, którzy weszli w to, chociaż nie chcieli walki politycznej, ale chcieli tylko robić to, co ich interesowało, to, co ich bawiło, czym żyli i prędzej czy później wchodzili w konflikt z władzami. Taki konflikt mógł pojawić się gdziekolwiek,

51 Archiwum autora. Rozmowę z Karlem Jungwirthem przeprowadził Lukáš Valeš, Klatovy 3 II 2002 r. 
czy to przy własnej twórczości literackiej, własnej twórczości muzycznej, w życiu zgodnie ze swą wiarą, wówczas głównie chyba chrześcijańską, inne prądy się raczej nie pojawiały, ale też w dziedzinie dajmy na to ochrony środowiska, wychowania młodzieży itd. Myślę więc, że bym to podzielił na 1:9, jakiś jeden zdecydowanie polityczny pogląd i dziewięciu ludzi, którzy nie chcieli robić polityki i weszli do tego tylko ze względu na ten jeden element, obronę podstawowych praw człowieka po konferencji helsińskiej, czy cokolwiek innego" ${ }^{2}$.

Wszystko więc wskazywało na to - przynajmniej tak wówczas przypuszczali nasi narratorzy - że Czechosłowacja bardzo powoli wejdzie na radziecką drogę stopniowej demokratyzacji. Tym większym zaskoczeniem był dla nich Listopad 1989, który dla większości z nich oznaczał konieczność bezpośredniego wejścia do polityki. Ich zachowanie było znowu motywowane powodami, dla których w ogóle podjęli działalność antyreżimową. Kiedy tylko stało się oczywiste, że rewolucja zwyciężyła, a reżim już nie ma dosyć sił i woli, by się utrzymać, zdecydowana większość z nich znów odeszła z polityki (często już po strajku generalnym, niektórzy w ciągu 1990 r.), by w pełni poświęcić się swojej działalności obywatelskiej. „Kiedy mnie ktoś pyta, po co to robiłeś... To nie była jakaś tam działalność. To była normalna ludzka postawa. To nie był mój świadomy styl życia czy założenie, program. To była moja postawa obywatelska, także później, kiedy zaczęliśmy robić z Klatovach rewolucję. To nie było tak, że my chcieliśmy robić rewolucję. To była demonstracja naszego przekonania, że bolszewik był zaprzedanym oszustem, z którym nie chcieliśmy mieć nic wspólnego i nic wspólnego nie mieliśmy. I to było nawet w porządku" ${ }^{53}$.

\section{Periodyzacja przebiegu}

\section{Aksamitnej Rewolucji na poziomie lokalnym}

Właściwą Aksamitną Rewolucję można podzielić na kilka faz:

Faza I - rewolucja. Fazę tę możemy podzielić na:

1. Etap informacyjny - ludzie spoza Pragi stopniowo dowiadują się o wydarzeniach 17 listopada w Pradze z plotek (w tym tej o rzekomej śmierci studenta Uniwersytetu Karola Martina Šmída, który miał zostać zabity

52 ÚSD, COH, zbiór Rozhovory. Rozmowę z inż. Petrem Náhlíkem przeprowadził Lukáš Valeš, Pilzno 22 I 2004 r.

53 Ibidem. 
przez komunistyczną bezpiekę na Národní Třídzie 17 listopada), tendencyjnych informacji z mediów oficjalnych, po bardziej obiektywne wiadomości zachodnich środków masowego przekazu itd. Informacje te wywierają na nich wpływ, a oni wyrabiają sobie własny pogląd. Jak mówi Michal Kučera: „Dokładnie to pamiętam. Jechaliśmy do Bíluk ze znajomym - to było koło obiadu - musiało to być 18 listopada. Na Rozhrání po drodze na stację benzynową mieliśmy w aucie włączoną »Wolną Europę« czy coś podobnego i tam właśnie powiedzieli, że w Pradze jest demonstracja, że zabito studenta Martina Šmída i że pobili ludzi. Dokładnie widzę widok z tego auta. Byłem strasznie zszokowany. No nie, oni zabili człowieka - wtedy w to naprawdę wierzyłem - że kogoś zabili. No a później w gazetach zupełnie nic..., byliśmy wściekli głównie na to, że oficjalne media milczały. Tylko w wiadomościach telewizyjnych była króciutka informacja o tym, że coś tam się stało. Ale w stylu - kilku agresywnych podżegaczy próbowało naruszyć porządek publiczny. W telewizji nie powiedzieli prawdy. My wiedzieliśmy od znajomych, co się działo" ${ }^{\text {"4 }}$. Kanały komunikacyjne były przy tym bardzo różnorodne, znaczącą rolę odgrywał fakt, że duża część społeczeństwa czeskiego ma bezpośrednio w Pradze rodzinę i znajomych, wielu praskich studentów pochodziło spoza Pragi itd. Najłatwiej miały, paradoksalnie, przede wszystkim tereny przygraniczne, najbardziej od Pragi oddalone, gdzie można było złapać sygnał zachodnioniemieckich i austriackich stacji telewizyjnych (ARD, ZDF, ORF itd.), które od 17 listopada przynosiły rozbudowane relacje bezpośrednio z Pragi. Mieszkańcy północnych terenów republiki śledzili z kolei informacje telewizji polskiej. Mimo tych informacji opinia publiczna w czeskich miastach, ze względu na dotychczasowe doświadczenia $\mathrm{z}$ reżimem, pozostawała raczej umiarkowanie sceptyczna niż optymistyczna i naprawdę niewielu przewidziało skutki wydarzeń w Pradze: „Wspominając rok 1968 większość nie brała pod uwagę, że tym razem sytuacja polityczna mogłaby się zmienić tak diametralnie, jak się zmieniła. Większość oczekiwała zmiany w kierownictwie KPCz. Oczekiwano, że dojdzie do liberalizacji, że będzie można podróżować, zakładać drobne przedsiębiorstwa, odnowić normalne funkcjonowanie stowarzyszeń. Mało kto oczekiwał, że zostanie zniesiona przywódcza rola Partii” ${ }^{\text {. }}$. „Nikt nie wierzył, że to stoi na

54 Archiwum autora, Rozmowa z małżeństwem Kučerovými, Klatovy 19 V 2003 r.

55 Archiwum autora, Rozmowę z inż. Janem Vránou przeprowadził Lukáš Valeš, Klatovy 11 XII 2001 r. 
takich glinianych nogach" ${ }^{\text {}}$. O tym, co będzie dalej, panowało jedynie bardzo mgliste wyobrażenie: „Nikt nie wiedział, co się stanie. Wierzyliśmy, że to nie będzie na stałe, ale nikt nie oczekiwał zwrotu o 180 stopni. Wszyscy oczekiwali rozwoju sytuacji takiego, jak w Rosji" ${ }^{\prime 57}$. Oczekiwano więc ewolucji, która miała trwać kilka lat: „Nikt nie przewidywał optymistycznie, że to doprowadzi do upadku reżimu" ${ }^{58}$. Etap ten trwa mniej więcej od 17 (18) listopada do pierwszej antyreżimowej demonstracji w danym mieście - na przykład 20 listopada w Pilznie, 22 listopada w Domaždicach (zachodnie Czechy), 22 listopada w Klatovach, 24 listopada w Mikulovie na południowych Morawach itd.

2. Etap mobilizacji - miejscowi, opozycyjnie nastawieni obywatele (czy grupy) zastanawiają się nad organizacją protestów antyreżimowych i korzystając ze swoich doświadczeń przygotowują pierwsze demonstracje. Ich celem jest uzyskanie poparcia opinii publicznej dla ruchu opozycyjnego i przesunięcie demonstracji antyreżimowych ze stolicy do innych miast Czechosłowacji. Wielką przeszkodę w realizacji tych zamiarów stanowił nie tylko reżim jako taki, jego instytucje, aparat represji itd., ale także od wielu dziesiątek lat kultywowana kultura małych miast, której podstawą były kontakty międzyludzkie. Małe place czeskich miast były bardziej na widoku niż anonimowa Praga - proporcjonalnie do tego wzrastało ryzyko ludzi, którzy starali się istniejące reguły, chociaż bezsensowne i znienawidzone, zmienić. Mówi o tym jedna z organizatorek demonstracji w Klatovach, inż. Jana Kučerová: „Ale ludzie wokół nas wszędzie w Klatovach mówili: »Co oni tam wyprawiają w tej Pradze«. No, to nas wściekło chyba najbardziej. Więc powiedzieliśmy sobie, że po prostu musimy powiedzieć, jak to jest. I kiedy już wiedzieliśmy, że w większych miastach organizuje się demonstracje - w Pradze każdego dnia - to powiedzieliśmy sobie, że to tutaj musimy zrobić też"59. Ten etap trwa w regionach od mniej więcej 19, 20 listopada, a jego kulminacją jest 27 listopada. Ważną cezurą jest pierwsza masowa manifestacja w miastach - podobna do stutysięcznej demonstracji na praskim Placu Wacława 20 listopada - kiedy to reżim po

56 Archiwum autora, Rozmowę z Karlem Jungwirthem przeprowadził Lukáš Valeš, Klatovy 3 II 2002 r.

57 Ibidem.

58 Archiwum autora, Rozmowę z prawnikiem Jiřím Štanclem przeprowadził Lukáš Valeš, Klatovy 7 I $2002 \mathrm{r}$.

59 Archiwum autora, Rozmowa z małżeństwem Kučerovými, Klatovy 19 V 2003 r. 
raz pierwszy zauważa rzeczywistą siłę ruchu antyreżimowego i powszechne poparcie dla rodzącej się opozycji. Ten właśnie etap był kluczowy dla sukcesu całej Aksamitnej Rewolucji. Poza zdolnościami organizacyjnymi i agitacyjnymi wymagał od inicjatorów wielkiej osobistej odwagi. Ludzie ci nie wiedzieli, na co się porywają, organizowali akcje przeciw reżimowi z pełną świadomością, że reżim ma nadal do dyspozycji wszystkie narzędzia władzy - armię, służby bezpieczeństwa - i że ma wszystkie środki, by przynajmniej tymczasowo ich pokonać. Dla ludzi z regionów kluczowe były ich kontakty z Pragą - poprzez znajomych czy krewnych; wielu spośród organizatorów demonstracji pochodziło z Pragi, czy studiowało tam i przez całe życie utrzymywało kontakty w stolicy. Dlatego też wielu ludzi z prowincji po pierwszych informacjach wyruszyło do Pragi, aby zorientować się, co się dzieje i przyniosło atmosferę rewolucji do swoich miast. Wspomina lekarz szpitala w Domaždicach, Hynek Faschinbauer, który po powrocie z rewolucyjnej Pragi zainicjował w swoim mieście pierwsze demonstracje: „...W środę rano opowiadałem w pracy o tym, co się dzieje w Pradze i że musimy coś podobnego zrobić tutaj. Powiedziałem, żeby wszyscy przyszli na plac o czwartej. Zapraszałem też ludzi spoza szpitala, w którym pracowałem, ale nie mówiłem im, o co chodzi - ze względu na gliniarzy... Zbiegiem okoliczności tego dnia przed południem miejscowe liceum miało jakiś wykład edukacyjny w tutejszym domu kultury, więc poszedłem do kolegi Vitii Podestáta, żeby tam przeczytał odezwę studentów z Pragi... W domu miałem pod poduszką flagę czechosłowacką... Wziąłem ją pod kurtkę i poszedłem. W szpitalu powiedziałem, że oczywiście może być tak, że nawet na plac nie dojdę, więc poszli ze mną jeszcze trzej koledzy. Miałem ze sobą Kartę praw i wolności obywatelskich, którą można było zupełnie normalnie kupić w każdym kiosku. W domu podkreśliłem w niej sobie hasła „swoboda wypowiedzi”, „swoboda zgromadzeń” itd. Miałem też jakieś ulotki z Pragi. Nikt nas nie zatrzymał i doszliśmy na plac. Przyszliśmy od strony klasztoru i już od początku zobaczyłem małe grupki ludzi, poznawałem swoich znajomych. Szedłem środkiem placu i widziałem, że ludzie idą ze mną. Doszedłem do kościoła, gdzie ze mną przyszło jeszcze chyba z 50 czy 60 osób i stopniowo przychodzili następni. Zacząłem klaskać i krzyczeć: »wolność«, »wolność«, i wszyscy się przyłączyli, no to wywiesiłem flagę, wszedłem na ławkę i przeczytałem coś z tej Karty. Opowiedziałem też o tym, co widziałem poprzedniego dnia w Pradze i przeczytałem oświadczenie protestacyjne studentów i już istniejącego Forum Obywatelskiego w Pradze... Na koniec zaprosiłem wszystkich na drugi dzień o tej 
samej godzinie"60. Warto przy tym zauważyć, że podobnie jak w innych miastach, także tę akcję monitorowała służba bezpieczeństwa - wielu jej pracowników było obecnych na manifestacji. Poza tym całą manifestację bezpieka nagrywała kamerami, umieszczonymi na ratuszu. To wywoływało w Hynku Faschingbauerze - podobnie jak w większości „pierwszych rewolucjonistów” - obawy przed aresztowaniem: „Mówiłem sobie, raz kozie śmierć. Byłem gotowy na wszystko - w tę albo we w tę. Po prostu czekałem na coś, bo widziałem na placu stojących estebaków i policjantów. Przeszedłem obok nich, żaden mnie nie zgarnął, więc szedłem dalej" ${ }^{61}$. Kulminacją tego etapu, a przy tym jednoznacznym dowodem na sukces rewolucji, był strajk generalny, zorganizowany przez Forum Obywatelskie w poniedziałek 27 listopada. Cała Czechosłowacja w samo południe na dwie godziny przerwała pracę, na placach odbywały się masowe demonstracje, w których wzięły udział praktycznie wszystkie grupy społeczne, w tym pracownicy wszystkich kluczowych przedsiębiorstw w kraju. Po tym sukcesie było jasne, że rewolucja zwyciężyła, a reżim komunistyczny musi tylko dokończyć negocjacje na temat warunków przekazania władzy.

3. etap postulatów. Jak już stwierdzono, właściwą Aksamitną Rewolucję na poziomie lokalnym zainicjowała specyficzna grupa ludzi, którzy stali gdzieś między sygnatariuszami antyreżimowych dokumentów, których zwykliśmy nazywać dysydentami, a „normalnym światem”. Ludzie ci byli przy tym dość zintegrowani wewnętrznie i niezbyt strachliwi (a do tego młodzi), aby w decydującym momencie, kiedy w ogóle nie było jasne, jak to się skończy - szczególnie w pierwszym tygodniu po 17 listopada - „wejść w to". To oni organizowali pierwsze antykomunistyczne demonstracje i zakładali, jeszcze przy znacznym ryzyku, Fora Obywatelskie w regionach. Ludzie z tej grupy biorą także udział w przekształcaniu nieformalnych dotychczas grup opozycyjnych w formalną organizację - Forum Obywatelskie. Potem - często już po sukcesie strajku generalnego 27 listopada - odchodzą z polityki. Ich cel został osiągnięty - już nie było odwrotu. Cytując słowacką aktorkę Lubę Blaškovičovą: „Swoje zadanie wykonaliśmy. Nie ma

60 Jak to tenkrát vlastně bylo? Rozhovor s MUDr. Hynkem Faschingbauerem. Vedl Josef Hrubý. „Domažlicko”, nr 47, 24 XI 1994, s. 6.

61 Před pěti lety se pro nás všechny změnil svět. Pokračování rozhovoru s MUDr. Hynkem Faschingbauerem. Vedl Josef Hrubý, „Domažlicko”, nr 48, 1 XII 1994, s. 6. 
powodu angażować się dalej, będziemy żyć normalnym życiem w wolnym społeczeństwie. Mogliśmy zrobić karierę. Mogliśmy, ale nie chcieliśmy"62.

Rosnące w siłę Forum Obywatelskie wybiera swoich rzeczników i formułuje postulaty, które zgłasza podczas pierwszych negocjacji z przedstawicielami dotychczasowych władz. Co charakterystyczne, za relewantną siłę nie jest przy tym uznawana KPCz. Negocjacje podejmują ludzie z kierownictwa miejscowych rad narodowych, którzy w reżimowej hierarchii władzy byli raczej outsiderami. Były to organy lokalnej czy miejskiej administracji państwowej, której przedstawiciele mogli decydować jedynie o kwestiach bieżącego funkcjonowania miast czeskich. Najważniejsze rozstrzygnięcia polityczne zapadały jednak w miejskich lub okręgowych komitetach KPCz. Chociaż i w tym przypadku chodziło o „sprawdzoną kadrę partyjną" - na przykład przewodniczący Miejskiej Rady Narodowej w miejscowości Stř́ibro w zachodnich Czechach Mirko Strankmüller był oficerem straży granicznej, przewodniczący Miejskiej Rady Narodowej w Klatovach Václav Turhober był oficerem Służby Bezpieczeństwa itd. - i chociaż także oni starali się początkowo zablokować rewolucję, podczas wydarzeń listopadowych pokazali zdecydowanie więcej realizmu politycznego i to nawet często jeszcze przed strajkiem generalnym, który pokazał prawdziwą siłę opozycji.

Przedstawiciele miejskich rad narodowych w odróżnieniu od funkcjonariuszy $\mathrm{KPCz}$ przejawiali więc od początku rewolucji - co najmniej od 24-25 listopada - znaczną dozę pragmatyzmu i właściwego wyczucia rozwoju sytuacji politycznej. Pewną rolę odegrać tu mógł osobisty pragmatyzm miejskiego aktywu, jego bliższy kontakt z prawdziwymi problemami codziennego życia obywateli, a także lepsza znajomość pogłębiających się problemów ekonomicznych (znaczące problemy z zaopatrzeniem), z którymi spotykali się jako przedstawiciele najniższego i ponoszącego największą odpowiedzialność organu administracji państwowej. Ich ocena realnych możliwości reżimu i, co za tym idzie, perspektyw jego dalszego istnienia, była zdecydowanie bliższa rzeczywistości niż często motywowane ideologicznie poglądy ich kolegów z aparatu partyjnego. Ich decyzja mogła wynikać także z lokalnego patriotyzmu, a może także z prawdziwego poczucia odpowiedzialności wobec obywateli danego miasta, co w owym okresie stało się ważniejsze niż dyscyplina partyjna. Przychodzi tu na myśl pewna paralela $\mathrm{z}$ negocjacjami na poziomie centralnym, gdzie partnerem dla

62 http://www.cassovia.sk/17november/bolisme.php3 (dostęp: 10 VIII 2009 r.). 
Forum Obywatelskiego byli także przedstawiciele administracji państwowej, w tym przypadku rządu czechosłowackiego z premierem Adamcem na czele, a nie sekretarze generalni $\mathrm{KPCz}$ Jakeš czy Urbanek.

Obie strony - przedstawiciele Forum Obywatelskiego i dotychczasowych komunistycznych władz miejskich - już podczas pierwszych rozmów deklarowały często wspólną troskę o dalszy rozwój miasta. Opozycja staje się przy tym równorzędnym partnerem i przedstawia swoje pierwsze postulaty wobec dotychczasowych władz - merytoryczne i personalne - przede wszystkim zmian w składzie rad i kierownictw miejskich rad narodowych. Analogiczna sytuacja ma miejsce w okręgowych radach narodowych, choć te są zarówno ideologicznie, jak i personalnie mocniej związane z organami KPCz. Etap postulatów trwa od 21-24 listopada do pierwszych zmian w radach - do połowy grudnia (w niektórych miejscach aż do połowy stycznia czy lutego).

Faza II - przejęcie władzy

Dotychczasowa opozycja, do której przyłączają się powstające partie polityczne (Partia Chrześcijańsko-Demokratyczna, Partia Zielonych, socjaldemokraci itd.), legitymizowana poparciem społeczeństwa, realizuje swoje postulaty i przejmuje władzę - między innymi dzięki ustaleniom „okrągłych stołów”, przy których spotykają się wszystkie relewantne siły polityczne w danym mieście. Pierwszym krokiem jest rekonstrukcja składu miejskich, okręgowych i krajskich rad narodowych (grudzień 1989 - luty 1990) najpierw spośród dotychczasowych członków, potem poprzez kooptację nowych i wybory przewodniczących rad narodowych. Ostatnia fala procesu kooptacji nowych członków kończy się w marcu-kwietniu 1990. Kulminacją procesu przejmowania władzy są wybory przewodniczących rad narodowych w lutym-marcu. Opozycja przejmuje władzę. Stopniowo dochodzą do głosu problemy codziennej polityki. Głównym celem na tym etapie było przełamanie dotychczasowego monopolu $\mathrm{KPCz}$ we władzach miast, okręgów i krajów, podczas gdy większość członków rad narodowych stanowili członkowie $\mathrm{KPCz}-\mathrm{w}$ zasadzie dwie trzecie, podobnie jak w plenach (obecnie radach miejskich). Istotnym elementem pierwszej fazy wymiany był fakt, że członkowie rad mogli być w tym momencie zastąpieni jedynie przez członków istniejących już plenów rad narodowych - w przeciwieństwie do późniejszych kooptacji. Między innymi to w znaczący sposób ograniczało pole manewru Forum Obywatelskiego. W skład nowych rad wejść mogły za to istniejące już partie - Czechosłowacka Partia Socjalistyczna i partia ludowa, wraz z bezpartyjnymi. Wpływ na wybór nowych 
202 członków rad miały przy tym nie tylko uzgodnienia przy okrągłych stołach, ale także dotychczasowe władze miast. To właśnie przewodniczący rad narodowych i ich sekretarze wiedzieli, kto spośród bezpartyjnych czy niekomunistycznych członków plenów ma choćby podstawowe przygotowanie merytoryczne do zarządzania miastami i gminami i właśnie ich wskazania czy propozycje były często decydujące. Składy i kierownictwa rad narodowych zyskały ostateczną formę dopiero po przyjęciu tzw. ustawy o kooptacji - nr 14/199o Dz.U. - przez Federalne Zgromadzenie Narodowe 23 stycznia $1990^{63}$. Zgodnie z nią partie polityczne i właściwe organy Frontu Narodowego mogły odwołać tych członków rad narodowych, którzy nie dawali gwarancji przestrzegania zasad demokracji. Na ich miejsce plenum właściwej rady narodowej mogło dokooptować nowych członków. Kooptacje te były zatwierdzone przez porozumienia przy okrągłych stołach i miały prowadzić do stworzenia takiego składu plenów rad narodowych, które odpowiadałoby „aktualnemu rozkładowi partii politycznych”. Oznaczało to między innymi masowe rezygnacje członków wybranych z ramienia $\mathrm{KPCz}$ i zastąpienie ich przez nowych, nominowanych przez Forum Obywatelskie i pozostałe partie demokratyczne. Jeżeli chodzi o skład polityczny plenów rad narodowych generalnie stosowano zasadę: $35 \%$ członków z KPCz, po $10 \%$ partia ludowa i partia socjalistyczna, a reszta zostawała dla bezpartyjnych, Forum Obywatelskiego i nowych podmiotów politycznych. Dopiero w tym momencie Forum Obywatelskie zyskało bezpośrednią reprezentację w plenach rad narodowych, a tym samym możliwość nominowania swoich przedstawicieli do kierownictwa. Bezpośrednio potem - w lutym i marcu - nastąpił maraton wyborów nowych przewodniczących, wiceprzewodniczących i sekretarzy rad narodowych. Dzięki swojej sile politycznej często zostawali nimi członkowie partii ludowej lub socjalistycznej, którzy nad Forum Obywatelskim mieli przewagę doświadczenia i kompetencji. Bardzo częstą praktyką - przede wszystkim w małych miastach i gminach - było przy tym, że zmiany te wcale nie były zasadnicze i część dotychczasowych przedstawicieli małych miast i gmin nadal pozostała na swych stanowiskach. Najbardziej znanym przykładem z zachodnich Czech jest tu

63 Więcej na ten temat zob.: L. Valeš, Obnova obecní samosprávy v kontextu české tranzice, [w:] Metamorfózy práva ve střední Evropè, red. H. Jetmarová, Z. Masopust, Praha 2008, s. 372-378; Z. Hledíková, J. Janák, J. Dobeš, Dějiny státní správy v českých zemích, Praha 2007. 
prawdopodobnie prawnik František Podlipský, który pierwszy raz został przewodniczącym miejskiej rady narodowej w miasteczku Bor, okręg Tachov, już w $1981 \mathrm{r}$. i pełnił tę funkcję stale aż do wyborów samorządowych w 2006 r., niezależnie od zmiany systemu ${ }^{64}$.

Faza III - stabilizacja

Wybory nowych władz miast, gmin, okręgów i krajów zakończyły fazę zmian politycznych; przyszła faza stabilizacji. Właśnie stabilizacja czy próba zachowania ciągłości, była znaczącym elementem czeskiej polityki lokalnej po Listopadzie - zarówno na poziomie personalnym, w relatywnie wolnym procesie zmian, jak i w ważnej sferze merytorycznych rozwiązań istniejących problemów - nowe władze, mimo diametralnie odmiennej orientacji politycznej, w przypadku przeważającej większości spraw szły drogą wyznaczoną przez politycznych poprzedników. Ów etap "merytoryczny” czy „stabilizacyjny" rozpoczyna się natychmiast po wyborze nowych przewodniczących rad narodowych (luty, marzec, a czasem także kwiecień 1990 r.), co było dobrze widoczne w planach posiedzeń plenów rad narodowych, gdzie znów w przeważającej większości dominowały pragmatyczne tematy codziennego administrowania, a „wielka polityka”, która do tej pory zaprzątała uwagę większości radnych, niemal znikła. Znaczącym wyjątkiem było przygotowanie czerwcowych wyborów parlamentarnych, pierwszych wolnych wyborów od ponad 4o lat, które były symboliczną kulminacją Listopada '89 i potwierdzeniem zwycięstwa dotychczasowej opozycji. Choć fazę tę określiliśmy stabilizacją, w jej ramach doszło do przynajmniej jednej rewolucyjnej zmiany w strukturze czeskiego samorządu - a więc do gigantycznego przyrostu nowych podmiotów samorządowych. Tylko w okresie od 1 lipca do 1 września 1990 r. niezależność zyskały 1684 gminy $^{65}$. Wykorzystały one powrót demokracji do przywrócenia swojej pierwotnej podmiotowości, którą utraciły za czasów reżimu komunistycznego. Zdecydowana większość z nich, dokładnie $88 \%$, były to gminy do 500 mieszkańców. W początkach reżimu komunistycznego w Czechosłowacji było według spisu ludności w 1950 r. 11459 gmin, po jedenastu latach - w roku 1961 - ich liczba spadła o prawie 3000 do 8726 gmin i trend ten utrzymywał się przez cały okres istnienia reżimu. Je-

64 L. Valeš, Zrod demokratických politických systémů okresů Klatovy, Domažlice a Tachov a jejich vývoj v 9o. letech 20. století, Pilzno 2007, s. 188.

65 Z. Vajdová, D. Čermák, M. Illner, Autonomie a spolupráce: důsledky ustavení obecního zř́zení v roce 1990, Praga 2006, s. 28. 
204 dyne wahnięcie nastąpiło w związku z liberalizacją lat 6o., kiedy liczba gmin spadła już „tylko” o ok. 1220 (do 7509 w 1970 r.) ${ }^{66}$, ale znów przyspieszył wraz z początkiem posttotalitarnego reżimu w okresie tzw. normalizacji. W ciągu 10 lat liczba gmin znowu zmniejszyła się o prawie 3000 do $4778 \mathrm{w} 1980 \mathrm{r}$. Potwierdzeniem i wzmocnieniem tego trendu był status tzw. gminy centralnej (czes. středisková obec) w 1982 r., co oficjalnie i instytucjonalnie potwierdzało zakończenie tego procesu. Obok likwidacji i łączenia gmin, odtąd gminy były zintegrowane w obwód administracyjny gminy centralnej. Wielkim problemem był biurokratyczny charakter tego procesu. Łączenie gmin odbywało się w sposób odgórny, bez względu na wolę mieszkańców, a także bez względu na tradycje historyczne tych miejscowości - podobnie jak łączenie okręgów w 1960 r.$^{67}$ Łączenie gmin zdecydowanie wzmocniło przy tym największe gminy, do których pozostałe były dołączane - właśnie tu pozostawała rada narodowa, czego skutkiem było często inwestowanie jedynie w rozwój gminy centralnej i zdecydowane niedofinansowanie pozostałych gmin w ramach jednego obwodu administracyjnego. W dalszej perspektywie prowadziło to do pogłębiania bierności i braku zainteresowania życiem publicznym czy też rozwojem i podniesieniem poziomu życia w miejscowości ze strony mieszkańców zintegrowanych gmin. Dlatego też w związku z generalną reformą czeskiej administracji samorządowej - a szczególnie z przyjęciem ustawy o ustroju gmin nr 367/199o Dz.U., która prowadziła do transformacji dotychczasowych lokalnych i miejskich rad narodowych w urzędy gminne i miejskie (ostatecznie po jesiennych wyborach samorządowych), doszło do bardzo dynamicznego i spontanicznego procesu częściowej przynajmniej reformy podstawowych jednostek samorządowych. Proces ten przebiegał różnie $\mathrm{w}$ zależności od regionu - w zachodnich Czechach prowadził do wzrostu liczby samodzielnych gmin o ponad $100 \%$, tymczasem na południowych Morawach chodziło o kilkadziesiąt nowych gmin.

W tej fazie doszło także do pierwszych konfliktów wewnątrz obozu dawnej opozycji. Rozpoczęły się one już w marcu 1990 r., w pełni ujawniły się po wyborach parlamentarnych, które z ogromną przewagą wygrało Forum Obywatelskie. Prowadziło to do wzmocnienia jego pozycji zwycięzcy,

66 Wpływ na to miała takze nowa ustawa o radach narodowych z 1967 r., która m.in. wprowadziła obligatoryjną zogdę dotychczasowych gmin i ich mieszkańców na integrację, P. Mates, M. Matula, Vybrané kapitoly z dějin a teorie veřejné správy, Praga 1999, S. 35.

67 L. Valeš et al., Politologické aspekty veřejné správy, Pilzno 2006. 
wzrostu pewności siebie u jego przedstawicieli w ramach istniejących już struktur rad narodowych i zdecydowanie mniejszej chęci do negocjowania kompromisów z innymi podmiotami politycznymi, co było powszechne jeszcze w pierwszej połowie 1990 r., kiedy to konsensus był ważniejszy niż natychmiastowy zysk polityczny. Postawa taka, związana m.in. z wejściem w skład kierownictwa lokalnych Forów bardzo ambitnych jednostek, miała jednak dla Forum Obywatelskiego także negatywne skutki - odejście z ich szeregów wielu znanych lokalnych osobistości, odpływ części sympatyków itd., co w niektórych miastach odbiło się negatywnie na wynikach Forum w wyborach samorządowych (np. w zachodnioczeskich Klatovach, gdzie w wyborach nie wygrało Forum, ale lista Partii Chrześcijańsko-Demokratycznej). W przypadku Forum Obywatelskiego w lecie 1990 r. możemy nawet mówić o swoistej „rewolucji menedżerów”, kiedy to o dalszym rozwoju Forum zaczęli decydować przede wszystkim menedżerowie, tj. aparat wykonawczy Forum Obywatelskiego. Właśnie ich siła polityczna zdecydowała m.in. o wyborze Václava Klausa - uosobienia pragmatyzmu - na przywódcę w październiku 1990. Wszystko to przyczyniło się do swoistego „otrzeźwienia” mieszkańców czeskich miast i gmin. Zmiana reżimu nie prowadziła automatycznie do spełnienia oczekiwań ludzi. Pojawiły się nowe problemy, związane z transformacją ekonomiczną i społeczną - prywatyzacja, związana z powrotem byłych działaczy partyjnych, ale także tzw. vekslaków [czeski odpowiednik cinkciarzy, spekulantów, kombinatorów, „załatwiaczy” - przyp. tłum.], bezrobocie itp. Spory między demokratycznymi siłami politycznymi i kryzys w Forum Obywatelskim były szeroko komentowane w mediach i przyczyniły się do demitologizacji polityki demokratycznej. Przejawem tej frustracji był prawie 25-procentowy spadek frekwencji w wyborach samorządowych w porównaniu z parlamentarnymi. Te negatywne zjawiska i niespełnione oczekiwania symbolicznie nasiliły się w dniu pierwszej rocznicy 17 listopada. Niemniej jednak wraz wyborami samorządowymi życie polityczne w Czechosłowacji weszło w nową - w pełni demokratyczną - fazę.

Faza IV - standaryzacja

Faza ta związana jest właśnie z jesiennymi wyborami samorządowymi, które odbywały się 24 listopada 1990 r. i z okresem bezpośrednio po nich. W wyniku tych wyborów miasta i gminy zyskały całkowicie demokratycznie wybraną elitę polityczną, która przejęła władzę. Okręgowe rady narodowe przekształciły się w organy administracji publicznej - urzędy okręgowe, a poziom krajski administracji był zlikwidowany bez następców. Walka po- 
206 lityczna także weszła w nową fazę - nie prowadziła już do czarno-białego podziału, jak podczas czerwcowych wyborów do parlamentu, które były raczej referendum: $\mathrm{KPCz}$ czy FO, ale po raz pierwszy doszło do konfliktu (chociaż nadal bardzo łagodnego) między nowymi podmiotami politycznymi, w którym KPCz i FO były tylko jednymi z kilku, chociaż nadal najważniejszymi. Wybory te oznaczały więc pełną reformę polityki, a więc także definitywną reformę samorządu terytorialnego.

\section{Zakończenie}

Studium niniejsze jest próbą zebrania i uogólnienia dotychczasowego stanu wiedzy o przebiegu Aksamitnej Rewolucji w Czechosłowacji na poziomie miast i regionów. Dotychczasowe badania wskazują, że, z wyjątkiem specyficznych rejonów, jakimi w epoce reżimu komunistycznego był na przykład Kraj Północnomorawski z silną koncentracją przemysłu ciężkiego i bardzo restrykcyjnym kierownictwem KPCz, przebieg Aksamitnej Rewolucji nie różnił się zbytnio w poszczególnych krajach ówczesnej Czechosłowacji czy ziem czeskich. Regiony reagowały stosunkowo szybko na wydarzenia w Pradze jako centrum wydarzeń. Pierwsza wielka demonstracja przebiegła w Pradze 20 listopada 1989 r., tego samego dnia doszło także do pierwszych, chociaż zdecydowanie mniej licznych demonstracji w niektórych stolicach krajów (Pilzno), a w kolejnych dniach (21-24 listopada) do publicznych protestów w miastach okręgowych. Przebieg, tempo i intensywność wydarzeń rewolucyjnych, w tym także dynamika, z jaką dochodziło do stopniowego przekazywania władzy przez dotychczasowych przedstawicieli reżimu komunistycznego opozycji, nie zależały pierwotnie od położenia geograficznego. Istotne nie było to, jak bardzo dane miasto było oddalone od Pragi. Decydujące były inne powody. Na przykład ekonomiczne. Jeżeli na przykład $w$ danym mieście istniał jeden wielki zakład, który zatrudniał, a tym samym wpływał na życie większości mieszkańców (na przykład miasto okręgowe Strakonice w południowych Czechach i fabryka ČZ czy północnomorawskie miasto Kopřivnice z producentem aut towarowych TATRA), kierownictwu zakładu udawało się we współpracy z organami $\mathrm{KPCz}$ znacząco opóźnić zmiany rewolucyjne.

Kolejnymi znaczącymi elementami były czynniki demograficzno-społeczne - to, jak wyglądała struktura społeczna i edukacyjna mieszkańców miasta, jaki tu był poziom życia politycznego i kulturalnego, czy dane miasto czy region rozwijały się relatywnie stabilnie, czy na przykład miało tu miejsce wysiedlenie niemieckich mieszkańców po II wojnie światowej i akcja osiedleńcza. 
W miejscach długotrwale nieprzerwanie osiedlonych, której mieszkańcy wykazywali silną tożsamość lokalną i przywiązanie do demokratycznych tradycji politycznych, a także rozwinęli sieć formalnych i nieformalnych zrzeszeń (sportowych, ekologicznych, kulturalnych itd.), istniała także zazwyczaj silna świadomość obywatelska, która w czasie rewolucji aktywizowała się i zmieniła w organizację protestów antyreżimowych, budowę struktur opozycyjnych i powstanie lokalnego Forum Obywatelskiego. W następstwie dochodziło do relatywnie szybkiego przejęcia władzy od dotychczasowych przedstawicieli rad narodowych. Natomiast w regionach, w których doszło do wysiedlenia i masowej migracji z bardziej zacofanych części Czechosłowacji, ze zdecydowanie niższym poziomem edukacji i ogólnie rzecz biorąc strukturą społeczną, w której brakowało silnego patriotyzmu lokalnego i świadomości obywatelskiej, zmiany zachodziły wolniej - i to w perspektywie tygodni i miesięcy (szczególnie jeżeli chodziło o ustanowienie nowych władz miast, okręgów i krajów). Ważnymi źródłami tradycji demokratycznych, które wyraźnie ujawniły się podczas wydarzeń listopadowych na poziomie lokalnym, była zarówno I Republika Czechosłowacka, związana z imieniem pierwszego prezydenta Tomasza G. Masaryka, pamięć o Praskiej Wiośnie i próbach reformy reżimu w 1968 r., ale także np. oswobodzenie części terytorium Czechosłowacji w 1945 r. przez wojska amerykańskie (a nie tylko sowieckie) - chodziło tu głównie o południowe i zachodnie Czechy.

Aksamitna Rewolucja 1989 r. na poziomie lokalnym była do niedawna raczej marginalnym tematem historiografii czeskiej. Pocieszające jest, że szczególnie dwudziesta rocznica Aksamitnej Rewolucji w 2009 r. oznaczała zdecydowaną zmianę i przyniosła szereg regionalnych prac na ten temat. Nowym impulsem dla tych badań stał się projekt „Průběh Sametové revoluce ve vybraných městech Jihočeského kraje v komparativní perspektivě v roce 2013 ", który nawiązywał do poprzednich badań w zachodnich Czechach. Zwiększonego zainteresowania tą problematyką oczekiwać należy w związku z 25. rocznicą rewolucji w 2014 r. Nowe badania umożliwią nam zdecydowane poszerzenie wiedzy o wydarzeniach Aksamitnej Rewolucji na poziomie lokalnym, a także porównanie ich przebiegu z innymi państwami postkomunistycznymi. Próba komparatystycznego ujęcia tematu będzie przedmiotem naszego kolejnego studium. 
Lukáš Valeš

Czech Opposition Structures at the Local Level in 1989 through the Eyes of Oral History
Studies Czech Opposition Structures at the Local Level in 1989 through the Eyes of Oral History is devoted to the description and analysis of anti-regime activities of czech society at the level of towns and regions. The main source of knowledge are mainly interviews with the participants, led by the method of oral history. The aim of the study is primarily to show the variety of activities that took place at the local level, despite the repressive power of the communist regime in Czechoslovakia. 